\title{
Inverse modelling to unravel the radiogenic isotope signature of mantle sources from evolved magmas: the case-study of Ischia volcano
}

\author{
Martina Casalini (1), Arnd Heumann (2), Sara Marchionni (1), Sandro Conticelli $(1,3)$, \\ Riccardo Avanzinelli $(1,3)$ \& Simone Tommasini (1)
}

\section{ABSTRACT}

The active volcano of Ischia, the well-known island off-shore the city of Naples, has had a discontinuous volcanic activity characterised by caldera-forming paroxysmal eruptions, lava flows, and lava domes for $>150$ kyr. The overall geochemical composition of erupted magmas includes shoshonite, latite, and trachyte/ trachyphonolite. In a complementary study, we demonstrated that the evolution of Ischia trachytes with $\mathrm{Sr}<100 \mathrm{ppm}$ occurred in a closed system environment, and depicted a scenario contemplating a complex magma chamber reservoir made up of multiple melt lenses isolated by largely crystalline mush portions. Here, we focus on the origin of the radiogenic isotope $(\mathrm{Sr}, \mathrm{Nd}, \mathrm{Hf}, \mathrm{Pb})$ signature of Ischia latites and trachytes with $100<\mathrm{Sr}<800 \mathrm{ppm}$, in the context of the recent Neapolitan District volcanic activity, and bearing in mind that no parental mantle-derived magma outcrops at Ischia. Parental mantle-derived basalts with $\mathrm{MgO}>10 \mathrm{wt}$ \% outcrop a few kilometers apart at Procida island, and suggest that the evolved latites and trachytes at Ischia might have originated by crustal assimilation processes affecting Procida basalts. However, Energy Constrained Assimilation and Fractional Crystallisation modelling sets robust constraints against this hypothesis and provide geochemical arguments for a pristine mantle-derived radiogenic isotope signature for trachytes and latites, implying that they also evolved from parental basaltic magmas in a closed-system environment akin to trachytes with $\mathrm{Sr}<100 \mathrm{ppm}$. This result corroborates the model presented in the complementary study suggesting a complex magma chamber reservoir formed by isolated magma batches with distinct radiogenic isotope compositions that evolved along similar liquid lines of descent and are separated by crystal mush zones.

The $\mathrm{Sr}, \mathrm{Nd}, \mathrm{Pb}$, and $\mathrm{Hf}$ isotope composition of Ischia latites and trachytes suggests metasomatic enrichment of a MORB-type asthenospheric mantle source by composite supercritical liquids originating from the altered oceanic basalt and pelagic sediment of the subducting Adriatic-Ionian slab. The results obtained on Ischia latites and trachytes, can be tentatively extended to the entire Neapolitan District volcanic system with important consequences for the isotopic signature of the mantle source and volcanic hazard assessment.

KEY WORDS: Ischia volcano, $\mathrm{Sr}-\mathrm{Nd}-\mathrm{Pb}$ - $\mathrm{H}$ f radiogenic isotopes, geochemistry, mantle source metasomatism, magma chamber dynamics.

(1) Dipartimento di Scienze della Terra, Università degli Studi di Firenze, via G. La Pira 4, Firenze, Italy.

(2) GFZ German Research Centre for Geosciences, Telegrafenberg, 14473 Potsdam, Germany.

(3) U.O.S. di Firenze, Istituto di Geoscienze e Georisorse, Consiglio Nazionale delle Ricerche, via G. La Pira 4, Firenze, Italy. Corresponding authors e-mail: simone.tommasini@unifi.it, riccardo. avanzinelli@unifi.it.

\section{INTRODUCTION}

The evolution of Ischia trachytes with $\mathrm{Sr}<100 \mathrm{ppm}$ occurred from parental magmas in a closed system environment (CASALINI et alii, 2017). In their study, the authors depicted a scenario contemplating a complex magma chamber reservoir made up of multiple discrete melt pockets isolated by largely crystalline mush portions (CASHMAN \& GioRdano, 2014). These evolved melt pockets, maintained in a steady-state thermal flux regime with no mass exchange, developed high $\mathrm{Rb} / \mathrm{Sr}\left({ }^{87} \mathrm{Rb} /{ }^{86} \mathrm{Sr}>100\right)$ permitting to measure ${ }^{87} \mathrm{Sr}$ ingrowth owing to the longlived history of magma storage in the order of a few 10s to 100 s of thousands of years.

In this paper, we focus on the origin of the radiogenic isotope $(\mathrm{Sr}, \mathrm{Nd}, \mathrm{Hf}, \mathrm{Pb})$ variability of Ischia latites and trachytes with $100<\mathrm{Sr}<800 \mathrm{ppm}$, in the context of the recent Neapolitan District volcanic activity, and bearing in mind that no parental mantle-derived magma outcrops at Ischia. This implies that the mantle-derived evolved latites and trachytes are liable to have been modified during open system processes, hence inhibiting our ability to use their radiogenic isotope signature to trace the geochemical characteristics of their mantle source in terms of metasomatic processes. In other words, the radiogenic isotope signature of the evolved Ischia latites and trachytes could either be unmodified and record the original mantle source signature (closed system assumption), or be affected by low pressure open system processes en route to the surface.

In this study we critically assess the occurrence of open system processes using the Energy Constrained Assimilation and Fractional Crystallisation (EC-AFC) model of SPERA \& BORHSON (2001), develop an inverse model to unravel the potential effects of assimilation processes, and shed light on the mantle source geochemical signature of Ischia magmas. The results obtained for Ischia latites and trachytes permit us to advance an exciting speculative scenario for the entire Neapolitan District volcanic system, which has important consequences for volcanic hazard assessment.

\section{VOLCANOLOGICAL BACKGROUND OF ISCHIA MAGMAS}

The active volcanoes of Ischia, Procida, Campi Flegrei, and Somma-Vesuvio, belong to the Neapolitan 
District (Fig. 1, inset) and form the southernmost cluster of volcanoes of the Roman Magmatic Province (e.g., Washington, 1906; Conticelli et alii, 2004, 2010; 2015; Peccerillo, 2005; Avanzinelli et alii, 2009).

The island of Ischia is the remnant of a larger volcanic edifice located at the northwestern corner of the Gulf of Napoli (Fig. 1, inset). The subaerial portion of the Ischia volcano $\left(\sim 46 \mathrm{~km}^{2}\right)$ is composed of pyroclastic rocks with minor lava flows and domes, landslide deposits, and terrigenous sedimentary rocks (DE VITA et alii, 2006, 2010; Della Seta et alii, 2012, and references therein). The morphology of the island reflects a complex history of alternating constructive and destructive phases, due to the interplay among tectonics, volcanic activity, and gravitational surface movements (e.g., VEzzoLI, 1988; ORSI et alii, 1991, 2003; Acocella \& Funiciello, 1999; Acocella et alii, 2001, 2004; DE VITA et alii, 2006, 2010; Della SETA et alii, 2012). The subaerial volcanic activity of Ischia has been divided into five main phases (Fig. 1) on the basis of radiometric ages and stratigraphic, geochemical, and radiogenic isotope data (e.g., GILlot et alii, 1982; Poli et alii, 1987, 1989; Vezzoli, 1988; CRIsci et alii, 1989; CIVETTA et alii, 1991; Tibaldi \& Vezzoli, 2004; Brown et alii, 2008, 2014; Melluso et alii, 2014).

I Phase $(150-75 \mathrm{ka})$ is the oldest outcropping phase of subaerial volcanic activity, which erupted mainly trachyte and trachyphonolite lava flows and domes, along with minor pyroclastic rocks (e.g., Gillot et alii, 1982; VEzzoLI,
1988; CRIScI et alii, 1989; Brown et alii, 2014; Melluso et alii, 2014). The volcanic rocks of this phase outcrop discontinuously along the southernmost shoreline of the island, from Punta Imperatore to Punta San Pancrazio, and in scattered outcrops along the periphery of the island.

II Phase (75 - $55 \mathrm{ka})$ was marked by a change of the eruptive style from mainly effusive to highly explosive eruptions with emplacement of complex successions of trachytic pumice falls interlayered with pyroclastic density currents and breccias (Orsi et alii, 1991; Brown et alii, 2008). The volcanic rocks of this phase outcrop continuously along the southeastern sector of the island overlaying the rocks of the I phase.

III Phase (55 - $33 \mathrm{ka})$ started with the paroxysmal Mt. Epomeo Green Tuff eruption $\left(\sim 40 \mathrm{~km}^{3}\right.$ of pyroclastic products) which formed a $\sim 10 \times 7 \mathrm{~km}$ caldera (e.g., Vezzoli, 1988; Tibaldi \& Vezzoli, 1998; TomLinson et alii, 2014). The Mt. Epomeo Green Tuff consists of trachytic ignimbrites partially filling a submerged depression, which now makes up the central part of the island. Minor trachytic hydromagmatic to magmatic eruptions from small vents along the southwestern and northwestern sectors of the island prolonged this phase up to $33 \mathrm{ka}$ (DE VITA et alii, 2010).

IV Phase (28 - $18 \mathrm{ka})$ started after $5 \mathrm{kyr}$ of quiescence with the arrival of shoshonitic magma into the main reservoir, which triggered the Mt. Epomeo caldera resurgence of some $900 \mathrm{~m}$ (Poli et alii, 1989; CivetTa et alii,

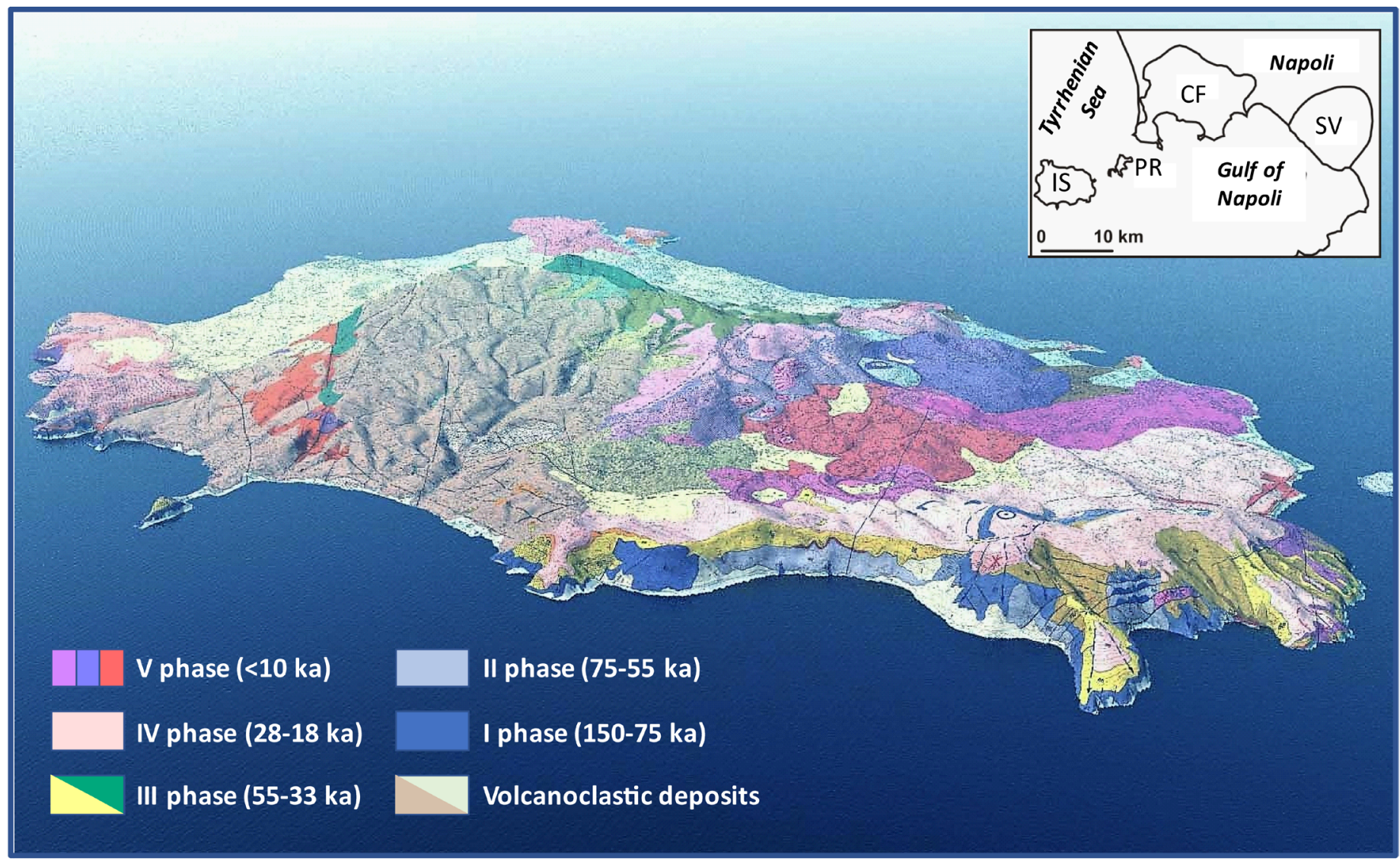

Fig. 1 - Simplified digital elevation model and geological map of Ischia from a SE view (after Orsi et alii, 2003; MonTI et alii, 2010). Inset: schematic map of the four active volcanoes of the Neapolitan District, belonging to the southernmost sector of the Roman Magmatic Province (IS = Ischia, PR = Procida, CF = Campi Flegrei, SV = Somma-Vesuvio). 
1991; Orsi et alii, 1991; DE VITA et alii, 2006). The products of this phase are scattered along the peripheral sectors of the island, at Mt. Vico, between Punta Imperatore and Mt. St. Angelo, and south of Castello.

V Phase (10 ka to present) is the last phase of activity and is characterized by mainly latitic to trachytic monogenetic volcanic activity and ongoing Mt. Epomeo caldera resurgence (e.g., ORsI et alii, 1991, 1996; BuchNER et alii, 1996; DE VITA et alii, 2006, 2010). The last historic lava flow eruption has been recorded at Mt. Arso in 1302 AD (DE VITA et alii, 2010, and references therein).

\section{ANALYTICAL TECHNIQUES}

Major and trace element analyses of 38 rock samples, collected along well-established volcanic log sequences representing the whole spectrum of magmas erupted during the five cycles of subaerial volcanic activity at Ischia ( $<150 \mathrm{ka}$ ), have been presented in the companion paper of CASALINI et alii (2017), along with Rb-Sr isotope dilution and ${ }^{87} \mathrm{Sr} /{ }^{86} \mathrm{Sr}$ data on mineral separates. In this study we focus on $\mathrm{Sr}, \mathrm{Nd}, \mathrm{Pb}$, and $\mathrm{Hf}$ isotope composition on 28 selected samples. $\mathrm{Sr}$ and $\mathrm{Nd}$ isotope analyses have been performed by magnetic sector multicollector Thermofisher Triton-Ti mass spectrometer at the Department of Earth Sciences, Università degli Studi di Firenze; $\mathrm{Pb}$ isotope analyses have been performed by MCICP-MS Thermo Fisher Neptune at the School of Earth Sciences, University of Bristol; Hf isotopes have been determined by MC-ICP-MS Thermo Fisher Neptune at the Department of Earth and Life Sciences, Vrije Universiteit of Amsterdam. Whole-rock samples have been dissolved in $15 \mathrm{ml}$ Savillex PFA beakers in a $\mathrm{HF}-\mathrm{HNO}_{3}-\mathrm{HCl}$ mixture after leaching with warm $\left(50{ }^{\circ} \mathrm{C}\right) 1 \mathrm{~N} \mathrm{HCl}$ for 1 hour in ultrasonic bath, and rinsing with Milli-Q water. $\mathrm{Sr}, \mathrm{Nd}, \mathrm{Pb}$, and $\mathrm{Hf}$ purification has been carried out using standard chromatographic techniques (e.g., Avanzinelli et alii, 2005; NeBel et alii, 2009). Sr and $\mathrm{Nd}$ isotopes have been measured in dynamic mode (AvANzINELLI et alii, 2005) and the effect of mass fractionation has been corrected using an exponential law to ${ }^{86} \mathrm{Sr} /{ }^{88} \mathrm{Sr}=0.1194$ and ${ }^{146} \mathrm{Nd} /{ }^{144} \mathrm{Nd}=0.7219$, respectively. $\mathrm{Pb}$ isotopes have been measured in static mode with a sample-standard bracketing technique (e.g., Avanzinelli et alii, 2014), and corrected for mass fractionation using an exponential law on the basis of the NIST SRM981 (BAKER et alii, 2004; ThIRlWAll, 2000). Hf isotopes have been determined in static mode using the analytical technique of NeBEL et alii (2009) and the ${ }^{176} \mathrm{Hf} /{ }^{177} \mathrm{Hf}$ were normalized to ${ }^{179} \mathrm{Hf} /{ }^{177} \mathrm{Hf}$ $=0.7325$ using an exponential mass fractionation law. All errors reported are within run precision $\left(2 \sigma_{m}\right)$ and, for $\mathrm{Nd}$ and $\mathrm{Sr}$, are typically $<10 \mathrm{ppm}$. Repeated analyses of NIST SRM 987 and a Nd internal standard (NdFi) yielded ${ }^{87} \mathrm{Sr} /{ }^{86} \mathrm{Sr}=0.710249 \pm 11(2 \sigma, \mathrm{n}=23)$, and ${ }^{143} \mathrm{Nd} /{ }^{144} \mathrm{Nd}=0.511467 \pm 8(2 \sigma, \mathrm{n}=15)$ over the period of analyses. The Nd isotope composition of the internal standard $\mathrm{Nd}-\mathrm{Fi}$ is referred to the La Jolla ${ }^{143} \mathrm{Nd} /{ }^{144} \mathrm{Nd}=$ $0.511847 \pm 7(2 \sigma, \mathrm{n}=53)$. The $\mathrm{Pb}$ isotopes standard bracketing technique reproducibility and accuracy was tested by several replicates of international rock standards (BCR2, BHVO2), and the NIST SRM $982\left({ }^{206} \mathrm{~Pb} /{ }^{204} \mathrm{~Pb}=\right.$ $36.755 \pm 15,{ }^{207} \mathrm{~Pb} /{ }^{204} \mathrm{~Pb}=17.166 \pm 6,{ }^{208} \mathrm{~Pb} /{ }^{204} \mathrm{~Pb}=36.754$ $\pm 16,2 \sigma, \mathrm{n}=23$ ), whose results are within error of their literature values (Woodhead \& Hergt, 2000; Collerson et alii, 2002; BAKER et alii, 2004; WeIs et alii, 2006). The JMC475 international standard yielded ${ }^{176} \mathrm{Hf} /{ }^{177} \mathrm{Hf}=0.282160$ $\pm 10(2 \sigma \mathrm{n}=15)$. Total procedural blanks were $<290 \mathrm{pg}$ $(\mathrm{Sr}),<120 \mathrm{pg}(\mathrm{Nd}),<90 \mathrm{pg}(\mathrm{Pb}),<25 \mathrm{pg}(\mathrm{Hf})$, and required no correction to the samples.

\section{PETROGRAPHIC, GEOCHEMICAL, AND RADIOGENIC ISOTOPE OUTLINES}

Petrographic and geochemical characteristics of the studied samples have been extensively reported in the companion paper of CASALINI et alii (2017). Here we present a brief and synthetic summary. Most of the samples are porphyritic trachytes and trachytes/phonolites lava flows, domes, and pumices with sanidine, plagioclase, clinopyroxene phenocrysts in a micro- to crypto-crystalline (lava flow and dome) to hyaline (pumice) groundmass made up of feldspar laths, clinopyroxene, biotite, magnetite \pm glass, with accessory magnetite, sphene, and apatite. The overall petrographic characteristics of the studied samples are consistent with previous studies on the same volcanic log sequences (e.g., Civetta et alii, 1991; Di Girolamo et alii, 1995; D’Antonio et alii, 2013; Brown et alii, 2014; Melluso et alii, 2014, and references therein).

Ischia volcanic rocks belong to the shoshonitic series within the Neapolitan District of the Roman Magmatic Province (i.e., KS or low-K series, Appleton, 1972; Conticelli et alii, 2010; D'ANTONIO et alii, 2013). The major element composition of the studied magmas at Ischia varies from shoshonite to latite, trachyte, and phonolite (Fig. 2), and covers the whole spectrum of composition reported in the literature (e.g., POLI et alii, 1987; CIVETTA et alii, 1991; Conticelli et alii, 2010; BRown et alii, 2014; Melluso et alii, 2014, and references therein). Most of the samples collected in this study straddle the trachyte-

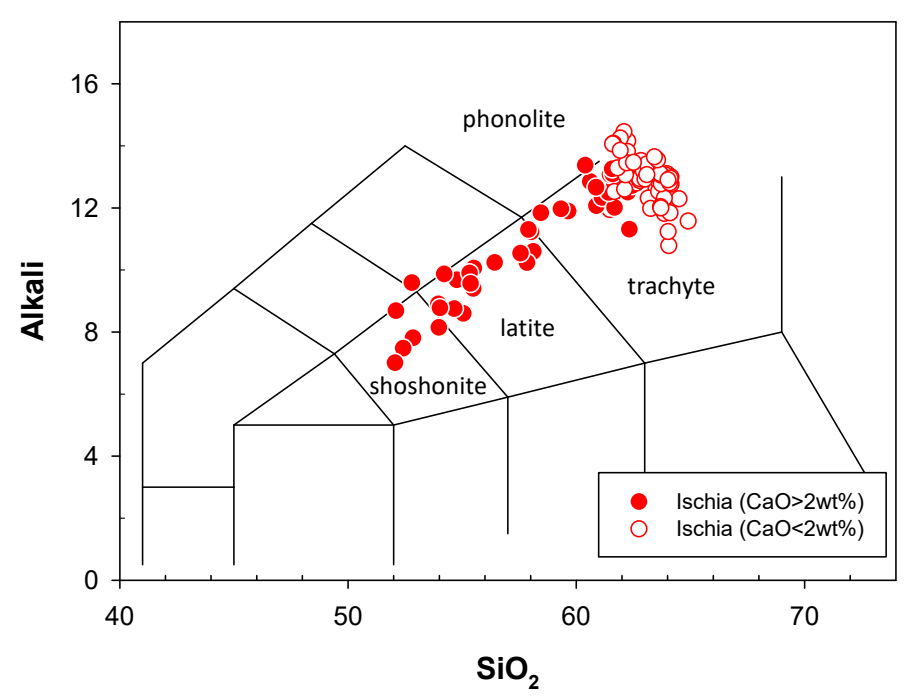

Fig. 2 - TAS classification diagram (LE MAITRE et alii, 2002) of the Ischia volcanic rocks. Solid and open red circles refer to less- and moreevolved samples with $\mathrm{CaO}>2 \mathrm{wt} \%$, and $\mathrm{CaO}<2 \mathrm{wt} \%$, respectively. Data source from Poli et alii (1987, 1989), Vezzoli (1988), CRISCI et alii (1989), CIVETTA et alii (1991), Orsi et alii (1992), Di GIROLAMO et alii (1995), PIOchi et alii (1999), D'ANTONIo et alii $(2007,2013)$, Brown et alii (2008, 2014), Melluso et alii (2014), Casalini et alii (2017). 
phonolite boundary (hereafter trachyte as a whole), with minor latites and shoshonites. Trachytes are generally rich in alkali with respect to alumina, straddling the boundary between peralkaline and metaluminous rocks.

The geochemical evolution of Ischia magmas from shoshonite through latite, and trachyte is characterized by an abrupt compositional variation of the liquid line of descent at $\sim 2 \mathrm{wt} \% \mathrm{CaO}$ (e.g., Brown et alii, 2014). Magma compositional variation from shoshonite $(\mathrm{CaO} \sim 7 \mathrm{wt} \%)$ to trachyte $(\mathrm{CaO} \sim 2 \mathrm{wt} \%)$ exhibits a decrease in $\mathrm{MgO}$, $\mathrm{FeO}, \mathrm{TiO}_{2}$, and $\mathrm{P}_{2} \mathrm{O}_{5}$ coupled with an increase in $\mathrm{SiO}_{2}$, $\mathrm{K}_{2} \mathrm{O}$, and $\mathrm{Na}_{2} \mathrm{O}$. Magma compositional variation within trachyte ( $\mathrm{CaO}$ from $\sim 2 \mathrm{wt} \%$ to $\sim 0.8 \mathrm{wt} \%$ ) continues along the same liquid line of descent for all major elements but $\mathrm{K}_{2} \mathrm{O}$ that exhibits a significant decrease. Incompatible trace elements (High Field Strength Elements, Rare Earth Elements, and most Large Ion Lithophile Elements) have a smooth increase from $7 \mathrm{wt} . \%$ to $2 \mathrm{wt} \% \mathrm{CaO}$, and then a rapid two- three-fold increase from $2 \mathrm{wt} . \%$ to $0.8 \mathrm{wt} \%$ $\mathrm{CaO}$, whilst transition metals, $\mathrm{Sr}$, and $\mathrm{Ba}$ show a positive and continuous correlation with $\mathrm{CaO}$ (e.g., CASALINI et alii, 2017). Magma temperature (BRown et alii, 2014; Melluso et alii, 2014) decreases with magma evolution from 1030$880{ }^{\circ} \mathrm{C}$ for a mafic inclusion within the Zaro shoshonite
(Sr $\sim 500 \mathrm{ppm})$ to $930^{\circ} \mathrm{C}$ for a trachyte $(\mathrm{Sr} \sim 100 \mathrm{ppm})$, and $700-770{ }^{\circ} \mathrm{C}$ for another trachyte $(\mathrm{Sr} \sim 10 \mathrm{ppm})$.

The Ischia volcanic rocks have $\mathrm{Sr}, \mathrm{Nd}$, and $\mathrm{Pb}$ isotope compositions transitional between those of Procida and Somma-Vesuvio within the Neapolitan District (Table 1, and Figs. 7 and 8) (e.g., Сivetta et alii, 1991; Рiоchi et alii, 1999; D’Antonio et alii, 1999, 2007, 2013; Conticelli et alii, 2002, 2010, 2015; AvANZINELLI et alii, 2008, 2009; Mazzeo et alii, 2014). In terms of $\mathrm{Sr}, \mathrm{Nd}, \mathrm{Pb}$, and Hf isotope composition, Ischia magmas exhibit a complete overlap among shoshonite, latite, and trachyte (Table 1), with no systematic variation between more-evolved and less-evolved magmas. The overall radiogenic isotope composition is similar to that of typical subduction related magmas, and is consistent with the mantle source heterogeneity recorded as a whole by the potassic and ultrapotassic magmas of the Roman Magmatic Province, in particular those of the Neapolitan District, pointing to variable addition of crustal components to the mantle wedge through the subduction process related to the Apennine orogeny (e.g., CRISCI et alii, 1989; Beccaluva et alii, 1991; Conticelli \& Peccerillo, 1992; D’ANTonio et alii, 1999, 2013; Peccerillo, 1999, 2001, 2005; Conticelli et alii, 2002, 2009, 2010, 2015; AvAnZINELli et alii, 2008, 2009; Moretti et alii, 2013; Mazzeo et alii, 2014).

\section{TABLE 1}

$\mathrm{Sr}, \mathrm{Nd}, \mathrm{Pb}$, and $\mathrm{Hf}$ isotope composition of the Ischia volcanic rocks

\begin{tabular}{|c|c|c|c|c|c|c|c|c|c|c|c|c|c|c|c|c|}
\hline Sample & Material & Locality & Phase & $\begin{array}{l}\text { age } \\
{[\mathrm{ka}]}\end{array}$ & $\mathrm{SiO}_{2}$ & Mg0 & $\mathrm{CaO}$ & $\mathrm{Sr}$ & ${ }^{87} \mathrm{Rb} /{ }^{86} \mathrm{Sr}$ & ${ }^{87} \mathrm{Sr} r^{86} \mathrm{Sr}_{\mathrm{m}} 2 \sigma_{\mathrm{m}}$ & ${ }^{87} \mathrm{Sr}^{186} \mathrm{Sr}_{\mathrm{i}}$ & ${ }^{143} \mathrm{Nd} /{ }^{144} \mathrm{Nd} 2 \sigma_{\mathrm{m}}$ & ${ }^{206} \mathrm{~Pb} /{ }^{204} \mathrm{~Pb}$ & ${ }^{207} \mathrm{~Pb} /{ }^{104} \mathrm{~Pb}$ & ${ }^{208} \mathrm{~Pb} / 204 \mathrm{~Pb}$ & ${ }^{176} \mathrm{Hf} /{ }^{177} \mathrm{Hf} 2 \sigma_{\mathrm{m}}$ \\
\hline ISC 03-01 & scoria cone & Molara Crater & V & 1,7 & 53,98 & 3,76 & 7,28 & 638 & 0,830 & $0,706364 \pm 7$ & 0,70636 & $0,512542 \pm 4$ & 18,993 & 15,690 & 39,134 & $0,282852 \pm 7$ \\
\hline ISC 03-09 & enclave & Zaro & V & 6 & 55,37 & 2,95 & 5,92 & 490 & 0,856 & $0,705375 \pm 6$ & 0,70538 & $0,512643 \pm 4$ & 19,018 & 15,686 & 39,134 & $0,282934 \pm 8$ \\
\hline ISC 03-03 & lava & Arso & V & 0,7 & 57,91 & 2,18 & 4,27 & 360 & 1,91 & $0,706392 \pm 7$ & 0,70639 & $0,512561 \pm 5$ & 19,021 & 15,688 & 39,150 & $0,282857 \pm 8$ \\
\hline ISC 03-04 & lava & Arso & V & 0,7 & 58,45 & 1,77 & 3,64 & 309 & 2,36 & $0,706372 \pm 8$ & 0,70637 & $0,512559 \pm 5$ & 19,021 & 15,689 & 39,150 & - \\
\hline ISC 03-06 & lava & Porto d'Ischia & $\mathrm{V}$ & 2,3 & 60,39 & 0,94 & 2,23 & 162 & 4,68 & $0,705903 \pm 7$ & 0,70590 & $0,512564 \pm 4$ & 19,061 & 15,691 & 39,192 & - \\
\hline ISC 03-05 & lava & Porto d'Ischia & V & 2,3 & 60,87 & 0,95 & 2,22 & 183 & 4,14 & $0,705883 \pm 6$ & 0,70588 & $0,512567 \pm 5$ & 18,971 & 15,685 & 39,092 & $0,282879 \pm 5$ \\
\hline ISC 03-02 & pumice & Cava Bianca & V & 10 & 61,58 & 0,64 & 1,81 & 126 & 6,38 & $0,706042 \pm 7$ & 0,70604 & $0,512567 \pm 4$ & 19,056 & 15,692 & 39,191 & - \\
\hline ISC 03-08 & lava & Zaro & $\mathrm{V}$ & 6 & 61,59 & 0,75 & 1,87 & 156 & 5,38 & $0,706082 \pm 7$ & 0,70608 & $0,512556 \pm 5$ & 19,062 & 15,693 & 39,197 & $0,282860 \pm 5$ \\
\hline ISC 03-17 & lava & Mt. Rotaro & $\mathrm{V}$ & 2,1 & 61,81 & 0,53 & 1,60 & 91 & 9,82 & $0,706110 \pm 7$ & 0,70611 & $0,512573 \pm 11$ & 19,049 & 15,692 & 39,186 & $0,282875 \pm 7$ \\
\hline ISC 03-07 & lava & Mt. Rotaro & V & 1,7 & 62,16 & 0,54 & 1,61 & 84 & 10,4 & $0,706109 \pm 7$ & 0,70611 & $0,512561 \pm 4$ & 19,050 & 15,689 & 39,179 & - \\
\hline ISC 03-12 & dome & Selva di Napolitano & $\mathrm{V}$ & 10 & 62,33 & 0,81 & 2,20 & 170 & 4,56 & $0,706051 \pm 7$ & 0,70605 & $0,512559 \pm 5$ & 19,069 & 15,695 & 39,209 & - \\
\hline ISC 10-04 & pumice & St. Angelo & $\mathrm{V}$ & 5,6 & 63,12 & 0,26 & 1,15 & 4 & 304 & $0,706320 \pm 5$ & 0,70630 & $0,512557 \pm 4$ & - & - & - & - \\
\hline ISC 03-11 & pumice & St. Angelo & IV & 19 & 62,24 & 0,73 & 1,17 & 13 & 96,1 & $0,708097 \pm 7$ & 0,70807 & $0,512536 \pm 5$ & 18,941 & 15,685 & 39,066 & - \\
\hline ISC $10-18$ & pumice & Pomicione & IV & 19 & 63,44 & 0,27 & 1,12 & 3 & 410 & $0,706295 \pm 7$ & 0,70618 & $0,512545 \pm 4$ & - & - & - & - \\
\hline ISC 03-13b & pumice & Mt. Eротео & III & 55 & 59,33 & 1,72 & 3,44 & 307 & 2,14 & $0,706781 \pm 7$ & 0,70678 & $0,512535 \pm 5$ & 19,146 & 15,703 & 39,287 & $0,282838 \pm 5$ \\
\hline ISC 03-13a & pumice & Mt. Epomeo & III & 55 & 59,64 & 2,04 & 3,61 & 246 & 2,83 & $0,706803 \pm 7$ & 0,70680 & $0,512538 \pm 5$ & 19,152 & 15,704 & 39,296 & - \\
\hline ISC 03-14 & pumice & Mt. Epomeo & III & 55 & 61,48 & 0,95 & 2,19 & 113 & 6,73 & $0,706819 \pm 7$ & 0,70681 & $0,512530 \pm 5$ & 19,110 & 15,698 & 39,241 & $0,282846 \pm 6$ \\
\hline ISC 03-15 & pumice & Mt. Vico & III & 38 & 63,16 & 0,43 & 1,26 & 31 & 38,5 & $0,707561 \pm 7$ & 0,70754 & $0,512525 \pm 4$ & 19,068 & 15,697 & 39,217 & - \\
\hline ISC $10-09$ & pumice & Punta Imperatore & III & 38 & 63,70 & 0,30 & 1,33 & 7 & 134 & $0,706213 \pm 8$ & 0,70614 & $0,512532 \pm 3$ & - & - & - & - \\
\hline ISC $10-08$ & pumice & Punta Imperatore & III & 38 & 63,74 & 0,28 & 1,31 & 4 & 247 & $0,706863 \pm 7$ & 0,70673 & $0,512528 \pm 5$ & - & - & - & - \\
\hline ISC 03-16 & lava & Mt. Vico & II & 75 & 61,63 & 0,40 & 1,09 & 4 & 375 & $0,708038 \pm 7$ & 0,70764 & $0,512544 \pm 5$ & 19,205 & 15,706 & 39,339 & $0,282852 \pm 4$ \\
\hline ISC $10-16$ & dome & Mt. Vico & II & 73 & 61,96 & 0,40 & 1,16 & 7 & 200 & $0,706658 \pm 13$ & 0,70645 & $0,512573 \pm 9$ & - & - & - & - \\
\hline ISC $10-12$ & lava & Campagnano & I & 130 & 61,58 & 0,32 & 1,03 & 12 & 124 & $0,706870 \pm 7$ & 0,70664 & $0,512560 \pm 4$ & - & - & - & - \\
\hline ISC $10-14 b$ & pumice & Piano Liguori & I & 130 & 61,66 & 0,70 & 2,07 & 251 & 2,75 & $0,706157 \pm 6$ & 0,70615 & $0,512558 \pm 4$ & - & - & - & - \\
\hline ISC 03-10 & dome & St. Angelo & I & 100 & 62,21 & 0,45 & 1,10 & 20 & 78,4 & $0,707866 \pm 7$ & 0,70775 & $0,512547 \pm 4$ & 19,222 & 15,708 & 39,355 & $0,282850 \pm 4$ \\
\hline ISC 10-01 & dome & St. Angelo & I & 100 & 62,92 & 0,42 & 1,04 & 22 & 67,5 & $0,707571 \pm 6$ & 0,70747 & $0,512551 \pm 4$ & - & - & - & - \\
\hline ISC $10-15 b$ & lava & Scarrupata di Barano & I & 126 & 64,03 & 0,34 & 0,94 & 12 & 106 & $0,706941 \pm 6$ & 0,70675 & $0,512538 \pm 5$ & - & - & - & - \\
\hline ISC $10-05$ & lava & Punta della Signora & I & 147 & 64,16 & 0,33 & 0,99 & 2 & 667 & $0,710120 \pm 26$ & 0,70873 & $0,512536 \pm 5$ & - & - & - & - \\
\hline
\end{tabular}




\section{DISCUSSION}

Given that no parental mantle-derived magma outcrops at Ischia, the origin of the radiogenic isotope $(\mathrm{Sr}$, $\mathrm{Nd}, \mathrm{Hf}, \mathrm{Pb}$ ) variability of latites and trachytes with $100<$ $\mathrm{Sr}<800 \mathrm{ppm}$, could be twofold: (i) original differences of the parental mantle-derived magmas or (ii) complex contamination processes affecting, independently, each discrete batch of magma. In other words, the radiogenic isotope signature of the evolved Ischia latites and trachytes could either record the original mantle source signature (closed system assumption), or be affected by low pressure open system processes en route to the surface.

In the following section, we critically assess the second hypothesis and its bearings on the mantle source signature underneath Ischia. Low pressure open system processes must take into account for the thermal budget of magmas, and this has been exhaustively presented by SPERA and co-authors in a number of papers (e.g., SPERA \& BORHSON, 2001) dealing with Energy Constrained Assimilation and Fractional Crystallisation processes (EC-AFC).

As noted above, there is no parental mantle-derived magma at Ischia, although parental mantle-derived basalts with $\mathrm{MgO}>10$ wt.\% outcrop in the nearby, a few kilometers apart, Procida island (e.g., D’ANTONIo et alii, 1999; MAzzeo et alii, 2014). It is therefore tempting to hypothesize that the evolved latites and trachytes at Ischia might be originated by crustal assimilation processes affecting the Procida basalts.

We have then used the EC-AFC software of SPERA \& Bohrson (2001) to predict the liquid lines of descent of Procida basalts in case of open system evolution. The assumptions we made to obtain the results discussed below are as follows (see also Table 2):

a. Two main magma reservoirs are present at Ischia (e.g., MoRETTI et alii, 2013; BRown et alii, 2014, and reference therein): the first at some $10-12 \mathrm{~km}$ depth, and the second at some $4-6 \mathrm{~km}$ depth. In our modelling, we considered that the open system process, if any, operated in the deeper reservoir. Actually, we also tried the ECAFC process at $4-6 \mathrm{~km}$ depth, although the results require special pleading to assimilate carbonate rocks occurring at those depths, and the liquid line of descent can be accounted for by fractional crystallisation alone.

b. The crustal rocks at $10-12 \mathrm{~km}$ depth can be safely represented by the metamorphic rocks of the Hercynian
Calabrian basement (Del Moro et alii, 2000; Fornelli et alii, 2002). In the dataset of Del Moro and Fornelli, they reported major, trace element, and $\mathrm{Sr}$ and $\mathrm{Nd}$ isotope compositions of a migmatite suite with leucosomes and melanosomes. As assimilated crustal material, we used the average composition of leucosomes as representative of crustal melts originated upon assimilation. This is to say that we used a bulk distribution coefficient (D) for each element equal to unity for the assimilated wall rock. Unfortunately, there is no $\mathrm{Hf}$ and $\mathrm{Pb}$ isotope composition of the Calabrian basement and we extrapolated these isotopic signatures from similar age crustal rocks of the Massif Central (Downes et alii, 1997) for $\mathrm{Pb}$ isotope composition, and from the strict positive correlation between $\mathrm{Hf}$ and $\mathrm{Nd}$ isotopes in terrestrial materials (e.g., Vervoort et alii, 1996) for Hf isotope composition. Using the actual trace element and radiogenic isotope composition of the assimilated material would change only slightly the result, although it would not invalidate the outcome of our EC-AFC modelling.

c. The initial wall rock temperature $\left(T a^{0}\right)$ has been set to $250{ }^{\circ} \mathrm{C}$ on the basis of a nominal geothermal gradient of $\sim 25{ }^{\circ} \mathrm{C} / \mathrm{km}$, and consistent with the ambient temperature of the country rock at $10-12 \mathrm{~km}$ depth, 'far away' from the contact with the magma reservoir as specified by SPERA \& BOHRSON (2001).

d. The initial temperature $\left(T m^{\circ}\right)$ of the Procida basalt has been set to $1250{ }^{\circ} \mathrm{C}$ on the basis of MELTS calculations (Gualda et alii, 2012; see also Mazzeo et alii, 2014). The temperature of Ischia latites and trachytes with $\mathrm{Sr}>100 \mathrm{ppm}$ ranges from $1030{ }^{\circ} \mathrm{C}$ to $930{ }^{\circ} \mathrm{C}$ on the basis of mineral geothermometers (BRown et alii, 2014; Melluso et alii, 2014). The equilibration temperature (Teq) of the system has been set to $900^{\circ} \mathrm{C}$ considering that the Ischia and Procida magmas have a spectrum of compositions from basalts to trachytes, hence the choice of Teq less than the eruptive temperature of the most evolved composition (SPERA \& BOHRSON, 2001). The solidus of the wall rock (TS) at $10-12 \mathrm{~km}$ has been set to $650{ }^{\circ} \mathrm{C}$ (e.g., Thompson, 1996).

e. The bulk distribution coefficients (D) of each element during the EC-AFC process have been determined using binary diagrams with $\mathrm{Sr}$ as differentiation index and trying to reproduce a liquid line of descent

TABLE 2

Energy Constrained Assimilation and Fractional Crystallisation (EC-AFC) models for Ischia magmas.

\begin{tabular}{|c|c|c|c|c|c|}
\hline \multicolumn{6}{|c|}{ Input parameters } \\
\hline magma liquidus temperature & Tlm & $1300^{\circ} \mathrm{C}$ & & $\begin{array}{l}\text { Procida } \\
\text { basalt }\end{array}$ & $\begin{array}{l}\text { assimilated } \\
\text { Calabrian basement }\end{array}$ \\
\hline initial magma temperature & $\mathrm{Tm} 0$ & $1250^{\circ} \mathrm{C}$ & $\operatorname{Sr}[\mathrm{ppm}]$ & 440 & 351 \\
\hline wall rock liquidus temperature & Tla & $950^{\circ} \mathrm{C}$ & ${ }^{87} \mathrm{Sr} /{ }^{86} \mathrm{Sr}$ & 0,7051 & 0,7166 \\
\hline initial wall rock temperature & $\mathrm{Ta} 0$ & $250^{\circ} \mathrm{C}$ & $\mathrm{D}^{\mathrm{Sr}}$ & 0,2 & 1 \\
\hline \multirow[t]{2}{*}{ wall rock solidus temperature } & Ts & $650^{\circ} \mathrm{C}$ & $\mathrm{D}^{\mathrm{Sr}}$ & 0,5 & 1 \\
\hline & & & $\mathrm{D}^{\mathrm{Sr}}$ & 1 & 1 \\
\hline \multirow[t]{2}{*}{ equilibration temperature } & Teq & $900^{\circ} \mathrm{C}$ & $\mathrm{D}^{\mathrm{Sr}}$ & 2 & 1 \\
\hline & & & $\mathrm{D}^{\mathrm{Sr}}$ & 4 & 1 \\
\hline
\end{tabular}

Synopsis of the input parameters of the three EC-AFC models for Ischia magmas (Figs. 3, 4, 5). The initial temperature of the Procida basalt is from MELTS (GuALDA et alii, 2012); the liquidus and solidus temperature of the wall rock has been assumed referring to THOMPson (1996). 
mimicking the composition of Ischia and Procida magmas and considering the proper fractionating mineral assemblage.

\section{ORIGIN OF Ischia Magmas WITH $\mathrm{SR}>100$ PPM}

\section{First case: one-step EC-AFC from Procida basalt}

On the basis of ${ }^{87} \mathrm{Sr} /{ }^{86} \mathrm{Sr}$ vs. Sr variation (Fig. 3), it could be hypothesized that Ischia latites and trachytes originated through open system processes starting from the Procida basalts, which have less radiogenic Sr isotope composition $\left.{ }^{87} \mathrm{Sr} /{ }^{86} \mathrm{Sr} \sim 0.705\right)$ and more primitive signature $(\mathrm{MgO}$ $>10$ wt. $\%$ ). To cover the entire compositional spectrum of Ischia magmas, the model EC-AFC process requires a significant range of $\mathrm{D}^{\text {Sr }}$ from 0.2 to 4 (Fig. 3). This is at odd with thermodynamic considerations, because different amounts of plagioclase, the major repository for Sr in this system, are claimed to crystallise from the same parental basalt. Also, the liquidus phases at $1250{ }^{\circ} \mathrm{C}$ on the Procida basalt are olivine and clinopyroxene, and plagioclase enters the crystallisation assemblage only at ca. $1150{ }^{\circ} \mathrm{C}$ (MELTS calculation). This make quite unlikely to produce a liquid line of descent with $\mathrm{D}^{\mathrm{Sr}}>1$ given that most $\mathrm{D}^{\mathrm{Sr}}$ in basalts are less than 2 (e.g., Rollinson, 1993). Left aside distribution coefficient inconsistency, the parental basalt maintains its original ${ }^{87} \mathrm{Sr} /{ }^{86} \mathrm{Sr}$ until the wall rock attains its solidus and then the ${ }^{87} \mathrm{Sr} /{ }^{86} \mathrm{Sr}$ increases significantly with proceeding evolution and at $930{ }^{\circ} \mathrm{C}$ reaches values more radiogenic than the $\mathrm{Sr}$ isotope composition recorded by Ischia latites and trachytes $\left({ }^{87} \mathrm{Sr} /{ }^{86} \mathrm{Sr}>0.710\right.$, Fig. 3$)$.

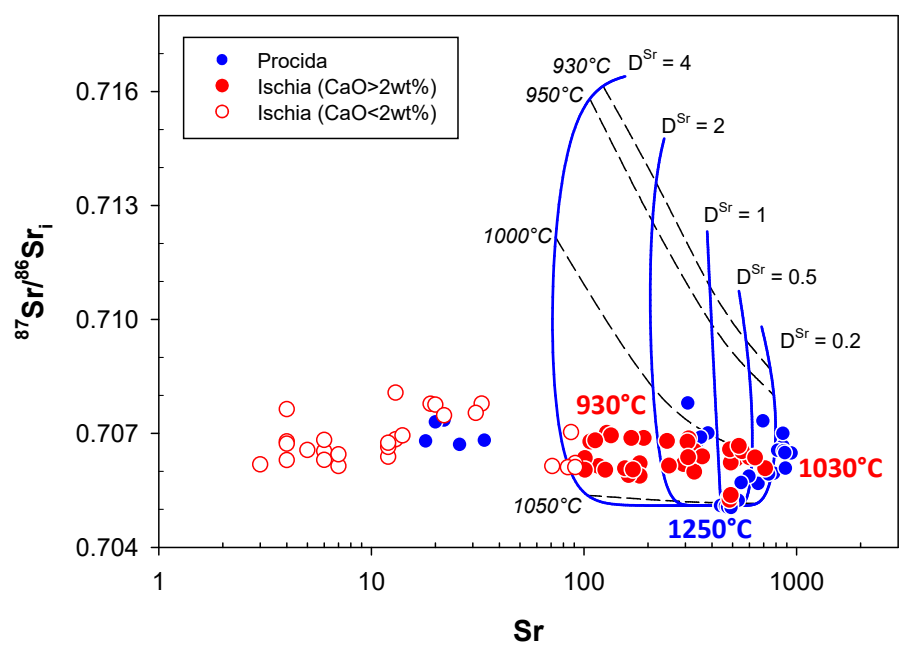

Fig. $3-{ }^{87} \mathrm{Sr} /{ }^{86} \mathrm{Sr}$ vs. Sr illustrating the evolution (solid blue lines) of Ischia magmas by one-step EC-AFC process from Procida basalts using different $\mathrm{D}^{\mathrm{Sr}}$ (see text for discussion). The temperature of evolving magmas along the five liquid lines of descent (in black) are derived from the EC-AFC model (see parameters in Tab. 2). The starting temperature fro Procida basalt (in blue) was estimated through rhyolite-MELTS 1.0 (GuALDA et alii, 2012), starting from the composition of a Procida basalt (i.e., APR18, D'ANTONIo et alii, 1999), with the following parameters: $\mathrm{P}=4$ kbar; $\mathrm{T}$ (liquidus) $1300{ }^{\circ} \mathrm{C} ; \mathrm{H}_{2} \mathrm{O}$ $=0.67 \%$; Oxygen fugacity $=\mathrm{OFM}$; the order of crystallisation was $\mathrm{Ol}$ $\rightarrow \mathrm{Cpx} \rightarrow \mathrm{Pl} \rightarrow$ oxides. The temperatures for Ischia magmas (in red) are from mineral geothermometers (BRown et alii, 2014; Melluso et alii, 2014). Data source for Ischia as in Fig. 2; Procida data are from D’ANTONIO et alii (1999), PAPPALARDo et alii (1999), De Astis et alii (2004), MAZzeo et alii (2014).

\section{Second case: two-steps EC-AFC from Procida basalt}

Another possible explanation of the ${ }^{87} \mathrm{Sr} /{ }^{86} \mathrm{Sr}$ vs. Sr variation of Ischia magmas could be a two-step EC-AFC process. The first step could be responsible to produce a liquid line of descent originating the less evolved latites of Ischia (and those of Procida as well, Fig. 4), whilst the second step could form the other latites and trachytes with Sr $>100$ ppm.

We have tried to model this two-step EC-AFC process and the result is reported in Fig. 4. Sr behaves as an incompatible trace element $\left(\mathrm{D}^{\mathrm{Sr}}=0.2\right)$ during the first step and as a compatible trace element $\left(\mathrm{D}^{\mathrm{Sr}}>1\right)$ during the second step, consistent with the crystallisation sequence of Procida basalt calculated using MELTS (i.e., olivine + clinopyroxene and then plagioclase).

In this case, we have modelled a liquid line of descent from $1250{ }^{\circ} \mathrm{C}$ to $1020{ }^{\circ} \mathrm{C}$ using a $\mathrm{D}^{\mathrm{Sr}}=0.2$ (Step I), and successively from $1020^{\circ} \mathrm{C}$ to $900{ }^{\circ} \mathrm{C}$ with a $\mathrm{D}^{\mathrm{Sr}}=9$ (Step II). The first EC-AFC step is liable to reproduce the Sr isotope composition and Sr content of the less evolved latites at Ischia and Procida. On the contrary, left aside that a $\mathrm{D}^{\mathrm{Sr}}=9$ for a latitic magma could be overestimated, the second ECAFC step produces a liquid line of descent that at $\mathrm{Sr}=100$ ppm and $900{ }^{\circ} \mathrm{C}$ has ${ }^{87} \mathrm{Sr} /{ }^{86} \mathrm{Sr}>0.712$, well beyond the values observed at Ischia. Also, it is to note that considering the magmas of the last 10 kyr (Fig. 4 inset), their Sr isotope signature decreases with $\mathrm{Sr}$ content, contradicting any assimilation process.

Third case: one-step EC-AFC from Procida basalt followed by a second step of closed system crystal fractionation process

The other possibility to account for the $\mathrm{Sr}$ isotope composition of evolved latites and trachytes at Ischia is that the second step of evolution occurs in a closed

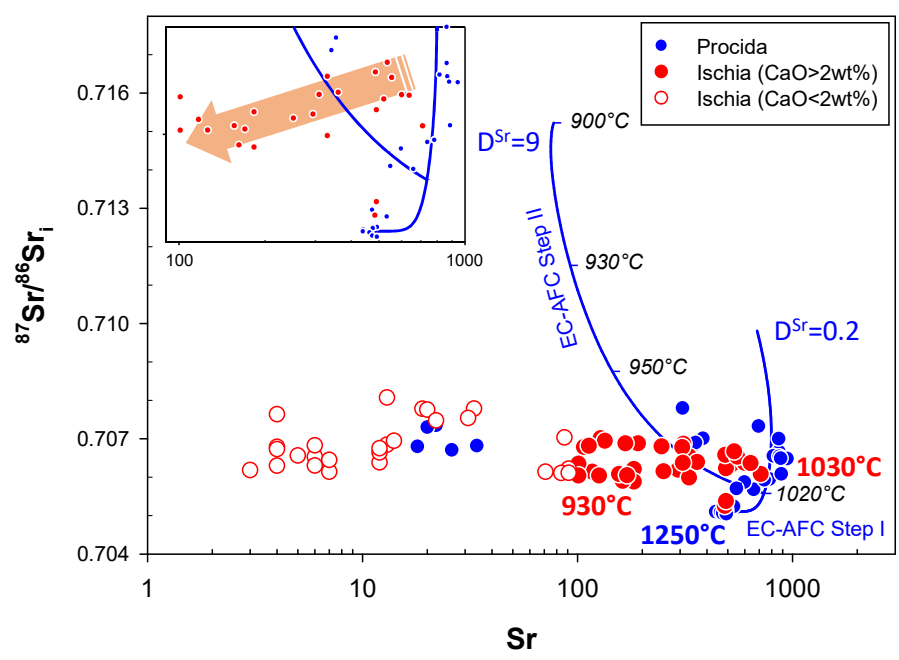

Fig. $4-{ }^{87} \mathrm{Sr} /{ }^{86} \mathrm{Sr}$ vs. Sr illustrating the evolution (solid blue lines) of Ischia magmas by two-steps EC-AFC process from Procida basalts using $\mathrm{D}^{\mathrm{Sr}}=0.2$ (Step I) and $\mathrm{D}^{\mathrm{Sr}}=0.9$ (Step II). The temperature of evolving magmas along the two liquid lines of descent is also reported along with temperature estimates for Procida (blue) and Ischia (red) magmas (see Fig. 3 for details). The decrease of ${ }^{87} \mathrm{Sr} /{ }^{86} \mathrm{Sr}$ with decreasing Sr content in magmas of the V Phase is reported in the inset (see text for discussion). Data source as in Fig.3. 
system environment, i.e. along a crystal fractionation liquid line of descent (Fig. 5). In this case we can envisage a scenario contemplating a first step of EC-AFC $\left(D^{\mathrm{Sr}}=0.2\right)$, which is liable to produce the overall ${ }^{87} \mathrm{Sr} /{ }^{86} \mathrm{Sr}$ spectrum of Ischia magmas, followed by a second step of closed system crystallisation dominated by plagioclase fractionation $\left(\mathrm{D}^{\mathrm{Sr}}=3.1\right)$ leading magma composition from latites $(\mathrm{Sr}=800 \mathrm{ppm})$ to trachytes $(\mathrm{Sr}=100 \mathrm{ppm})$ and operating on separated batches of magmas with different $\mathrm{Sr}$ isotope signature formed during the first EC-AFC step (Table 2).

The radiogenic $\mathrm{Sr}$ isotope composition of the Zaro enclave (Table 1, Fig. 5), similar to that of the parental Procida basalt, appears to set constraints on the occurrence of this process. The Zaro enclave could record the arrival of a magma similar to the Procida basalt at Ischia while experiencing the EC-AFC process. In principle the same process could explain also the $\mathrm{Sr}$ isotope composition and content of other relatively evolved magmas erupted at the neighbouring volcanoes Campi Flegrei and Vesuvio, although these fall further along the EC-AFC differentiation pathway (Fig. 5). At Vesuvio, however, previous studies based on experimental petrology and major element compositions, suggested a significant role for the assimilation of shallow carbonates (e.g., IACONO MARZIANO et alii 2009).

\section{Inverse modelling}

The third case hypothesis reported above can be tested by inverting the EC-AFC model. The second step of magma evolution at Ischia occurred in a closed system environment, and thus we can assume that the longlived isotope composition ( $\mathrm{Sr}, \mathrm{Nd}, \mathrm{Pb}, \mathrm{Hf}$ ) of each latitic to trachytic magma is the same that was achieved at the end of the first EC-AFC stage. Therefore, for each sample,

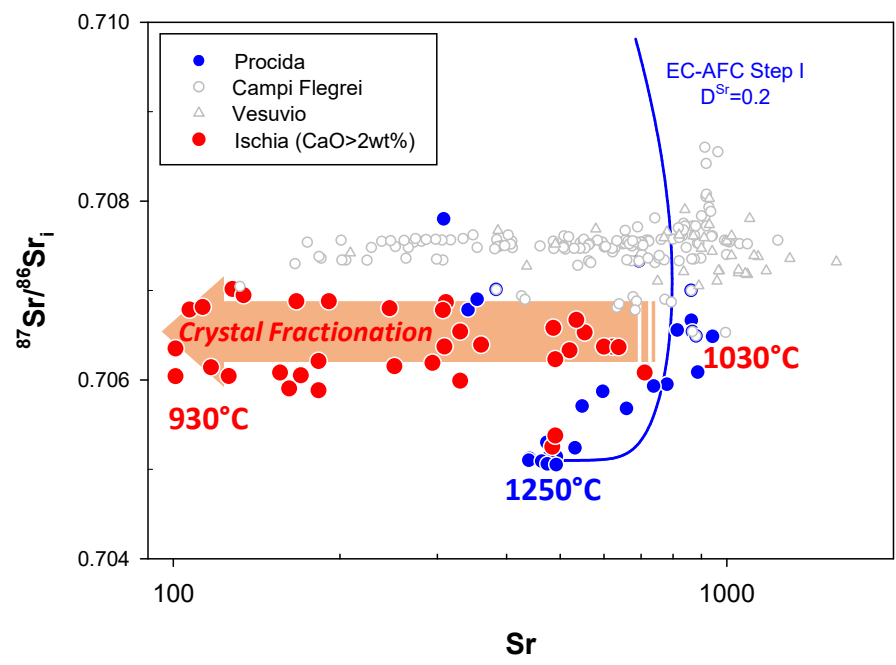

Fig. $5-{ }^{87} \mathrm{Sr} /{ }^{86} \mathrm{Sr}$ vs. Sr illustrating the evolution of Ischia magmas by one-step EC-AFC process from Procida basalts using $\mathrm{D}^{\mathrm{Sr}}=0.2$ (solid blue line) followed by closed system crystal fractionation with $\mathrm{D}^{\mathrm{Sr}}=$ 3.1. Temperature estimates for Procida (blue) and Ischia (red) magmas (see Fig. 3 for details) are also reported along with whole-rock data on Vesuvio and Campi Flegrei magmas (see text for discussion). Vesuvio and Campi Flegrei data are from CivetTa et alii (1997), Ayuso et alii (1998), D’Antonio et alii (1999), Pappalardo et alii (1999), Avanzinelli et alii $(2008,2018)$; other data source as in Fig. 3. it is possible to calculate back the radiogenic isotope composition of the parental, mantle-derived magma.

This has been carried out applying an inverse modelling to the output results of the EC-AFC process (SPERA \& BoHrSON, 2001):

The fraction of residual uncontaminated magma $F$ is given by:

$F=M_{m}-M_{a}$

Where $M_{m}$ is the total mass of contaminated magma at a given temperature, and $M_{a}$ is the total mass of melted wall rock incorporated into the magma body at the same temperature.

The elemental concentration in the magma considering a simple crystal fractionation process is given by:

$C l_{u n c}^{i}=C o^{i} \cdot F^{\left(D^{i}-1\right)}$

Where $C l_{\text {unc }}^{i}$ represents the content of element $i$ in the uncontaminated magma, $C o^{i}$ is the initial content of element $i$ in the uncontaminated magma, $F$ is from (1) and $D^{i}$ is the bulk distribution coefficient of element $i$.

The elemental concentration in the assimilated wall rock $\left(C_{a}^{i}\right)$ has been assumed to be equal to that of the leucosome average of the Calabrian basement, inasmuch as the leucosome represents the actual liquid formed upon melting the basement rocks. Given the fraction of residual uncontaminated liquid $F$ and the fraction of assimilated wall rock $M_{a}$, we can calculate the elemental content $\left(C l_{m}^{i}\right)$ in the total mass of contaminated magma $M_{m}$ :

$C l_{m}^{i}=\frac{F}{M_{m}} \cdot C l_{u n c}^{i}+\frac{M_{a}}{M_{m}} \cdot C_{a}^{i}$

Considering the two end-member mixing equation applied to isotopic compositions (e.g., Dickin, 1995):

$I R_{m}^{i}=\frac{I R_{u n c}^{i} \cdot C l_{u n c}^{i} \cdot F}{C l_{m}^{i}}+\frac{I R_{a}^{i} \cdot C_{a}^{i} \cdot M_{a}}{C l_{m}^{i}}$

Where $I R$ represents the radiogenic isotope composition of element $i$ (i.e., $\mathrm{Sr}, \mathrm{Nd}, \mathrm{Pb}, \mathrm{Hf}$ ) in the contaminated magma (subscript $m$ ), in the uncontaminated magma (subscript $u n c$ ), and in the assimilated magma (subscript $a$ ).

Given that the radiogenic $(\mathrm{Sr}, \mathrm{Nd}, \mathrm{Pb}, \mathrm{Hf})$ isotope composition of the contaminated magma derives from the first EC-AFC step at the different temperatures (EC-AFC output), the only unknown parameter in (4) is represented by the radiogenic isotope composition of element $i$ of the pristine mantle-derived magma $\left(I R_{u n c}^{i}\right)$, permitting to solve univocally (4) for $I R_{u n c}^{i}$.

We have applied this inverse modelling to the $\mathrm{Sr}, \mathrm{Nd}$, $\mathrm{Hf}$, and $\mathrm{Pb}$ isotope composition of the overall evolved Ischia magmas to estimate the isotopic signature of their pristine mantle-derived magma. Radiogenic $\mathrm{Sr}$ and $\mathrm{Nd}$ isotopes have been used as a check-point with respect to the Sr and $\mathrm{Nd}$ isotope composition of Procida basalts (e.g., D'ANTONIO et alii, 1999) used in the forward EC-AFC modelling.

The result of the inverse modelling is reported in Table 3 and Fig. 6. The ${ }^{87} \mathrm{Sr} /{ }^{86} \mathrm{Sr}$ and ${ }^{143} \mathrm{Nd} /{ }^{144} \mathrm{Nd}$ of the pristine mantle-derived magma is 0.70511 \pm 11 and $0.51270 \pm 2$, identical to the input composition of the Procida magma. However, the recalculated $\mathrm{Pb}$ isotope 
TABLE 3

Inverse modelling to calculate back the $\mathrm{Sr}, \mathrm{Nd}, \mathrm{Pb}$, and $\mathrm{Hf}$ isotope composition of Ischia mantle-derived magmas

\begin{tabular}{|c|c|c|c|c|c|}
\hline Element & $\mathrm{Sr}$ & $\mathrm{Nd}$ & $\mathrm{Hf}$ & $\mathrm{Pb}$ & \\
\hline Magma content [ppm] & 440 & 23 & 2 & 6 & \\
\hline $\mathrm{D}$ & 0,2 & 0,1 & 0,01 & 0,01 & \\
\hline Assimilant content [ppm] & 351 & 50 & 5,3 & 17 & \\
\hline $\mathrm{D}$ & 1 & 1 & 1 & 1 & \\
\hline Isotope & ${ }^{87} \mathrm{Sr} /{ }^{86} \mathrm{Sr}$ & ${ }^{143} \mathrm{Nd} /{ }^{144} \mathrm{Nd}$ & ${ }^{176} \mathrm{Hf} /{ }^{177} \mathrm{Hf}$ & ${ }^{206} \mathrm{~Pb} /{ }^{204} \mathrm{~Pb}$ & ${ }^{207} \mathrm{~Pb} /{ }^{204} \mathrm{~Pb}$ \\
\hline ratio in magma & 0,7051 & 0,5127 & & & \\
\hline ratio in assimilant & 0,7166 & 0,51207 & 0,2824 & 18,459 & 15,673 \\
\hline \multicolumn{6}{|c|}{ Inverse Modelling recalculation of mantle-derived magma } \\
\hline average ratio & 0,70511 & 0,51270 & 0,28301 & 19,37 & 15,71 \\
\hline $1 \mathrm{sd}$ & 0,00011 & 0,00002 & 0,00002 & 0,16 & 0,01 \\
\hline
\end{tabular}
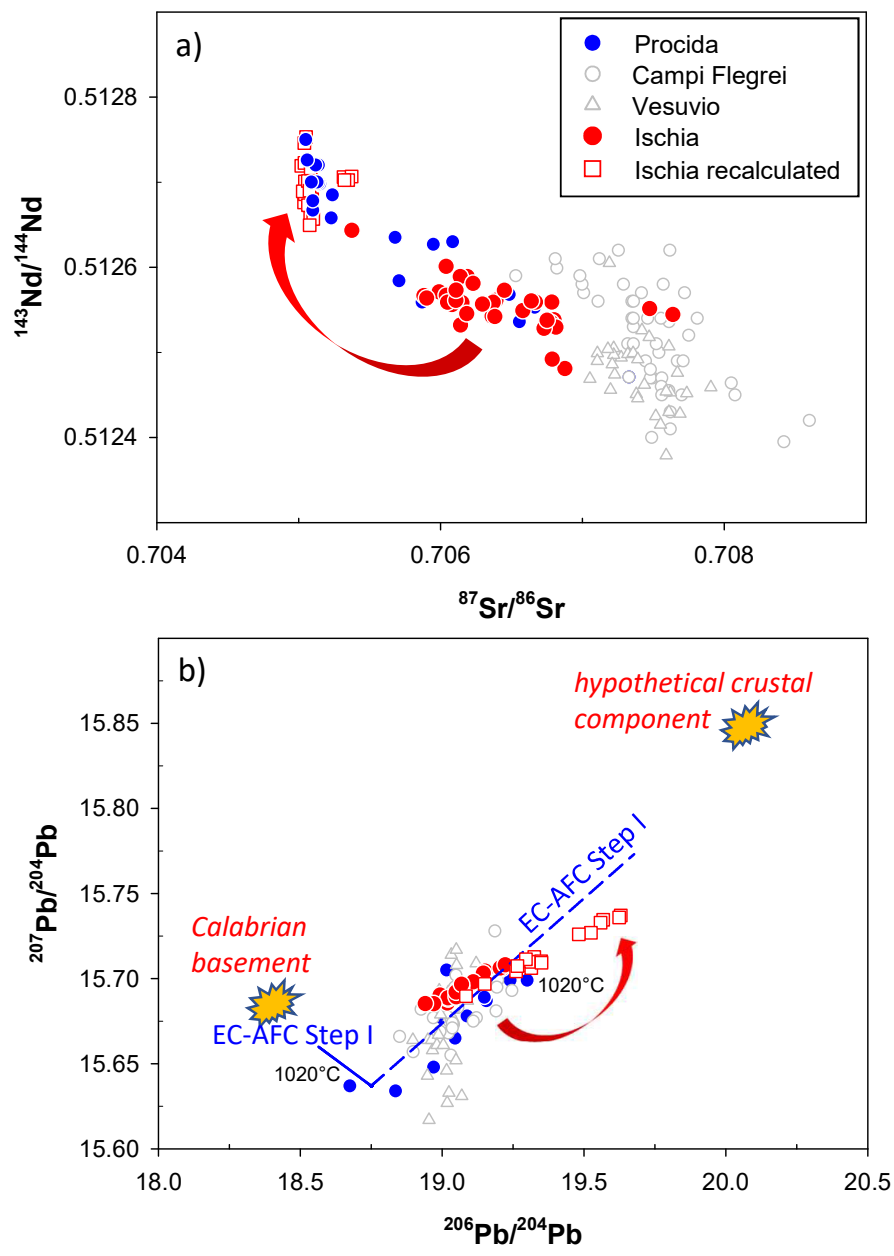

Fig 6 - Application of the inverse modelling developed in this study to recalculate back the $\mathrm{Nd}, \mathrm{Sr}(\mathrm{a})$, and $\mathrm{Pb}(\mathrm{b})$ isotope composition of the parental mantle-derived magmas of Ischia devoid of crustal contamination by the Calabrian Hercynian basement (Del Moro et alii, 2000; ForNell et alii, 2002). The recalculated $\mathrm{Pb}$ isotope composition is inconsistent with assimilation of crustal material and would necessitate a hypothetical crustal contaminant with an isotopic signature not occurring in sedimentary materials on Earth (see text for discussion). Data source as in Fig. 5. composition of Ischia magmas is totally inconsistent with that of the Procida basalt (Fig. 6b). This is because the EC-AFC process assimilating the Hercynian basement is unable to reproduce the $\mathrm{Pb}$ isotope composition of Ischia magmas (solid blue line, Fig. 6b) as it is the case for $\mathrm{Sr}$ and $\mathrm{Nd}$ isotopes (Fig. 6a). This is not a problem with the choice of the crustal contaminant: to reproduce the entire spectrum of $\mathrm{Pb}$ isotope composition of Ischia magmas we should have used a crustal contaminant with an isotopic signature not occurring in any sedimentary materials on Earth (dashed blue line, Fig. 6b).

This clearly shows that the EC-AFC model proposed above does not represent a viable process to explain the overall long-lived isotope composition of Ischia magmas.

The alternative explanation is, therefore, that the radiogenic isotope composition (and its variability) recorded in the relatively evolved products of Ischia volcano is directly inherited from that of its mantle source. In this scenario, magmas with significantly variable isotope composition were generated from a heterogeneous mantle source and were not completely homogenised during their upraise and storage within the crust.

The occurrence of discrete magma pulses with different radiogenic isotope signature unrelated to low pressure open-system processes en route to the surface, lends support to recent models of complex plumbing systems, made up of multiple discrete melt pockets, isolated by largely crystalline mush portions, maintained in a steady-state thermal flux regime with no mass exchange, and reactivated shortly before eruption (e.g., CASHMAN \& GIORDANO, 2014).

The geochemical arguments presented for Ischia magmas against EC-AFC processes could also apply to the entire Neapolitan district magmas. In this case, especially for Vesuvius, further modelling would be necessary in order to quantitatively address the possible effect of shallow carbonate assimilation (e.g., IACONO MARZIANO et alii, 2009). Such a process could be significant especially for $\mathrm{Sr}$ isotopes, whilst a smaller effect has to be expected for $\mathrm{Nd}$ and $\mathrm{Pb}$ isotopes, whose contents in the suggested wall-rock carbonates are negligible with respect to those of the magmas (Del Moro et alii, 2001). Similarly, Avanzinelli 
et alii (2018) recently demonstrated that assimilation of such a carbonatic wall rock at Vesuvio has little, if any, effect on the U-Th disequilibria measured in the lavas.

THE RADIOGENIC ISOTOPE SIGNATURE AND MANTLE METASOMATISM of Ischia aND OTHER NeAPolitan District Magmas

The isotopic lines of evidence presented here for Ischia, can be extended at a speculative assessment level to discuss the radiogenic isotope signature of the entire Neapolitan District magmas, in terms of the subduction-derived processes responsible for mantle enrichment. This sets the basis for upcoming and promising research investigating mantle processes starting from relatively evolved magmas.

Considering the recent volcanic rocks outcropping in Central and Southern Italy, the Ischia and Neapolitan District magmas have $\mathrm{Sr}$ and $\mathrm{Nd}$ isotope composition similar to Aeolian Islands magmas, although they tend to have slightly more radiogenic ${ }^{143} \mathrm{Nd} /{ }^{144} \mathrm{Nd}$ for a given ${ }^{87} \mathrm{Sr} /{ }^{86} \mathrm{Sr}$ (Fig. 7a). Overall, they define a trend starting from the $\mathrm{Sr}$ and $\mathrm{Nd}$ isotope signature available for the Tyrrhenian Sea basalts and pointing to ${ }^{87} \mathrm{Sr} /{ }^{86} \mathrm{Sr}=0.709$ and ${ }^{143} \mathrm{Nd} /{ }^{144} \mathrm{Nd}$ $=0.5124$. In other words, the Ischia and Neapolitan District magmas depart from the trend exhibited by Aeolian Islands and Roman Magmatic Province magmas. The same trend is exhibited on ${ }^{176} \mathrm{Hf} /{ }^{177} \mathrm{Hf}$ vs. ${ }^{87} \mathrm{Sr} /{ }^{86} \mathrm{Sr}$ diagram (Fig. $7 \mathrm{~b}$ ), albeit related to a much more limited database.

Remarkably, the $\mathrm{Pb}$ isotope signature of Ischia and Neapolitan District magmas (Figs. 8a, b) sets robust constraints on the completely different trend with respect to other recent magmas of Central and Southern Italy. On both ${ }^{206} \mathrm{~Pb} /{ }^{204} \mathrm{~Pb}$ vs. ${ }^{87} \mathrm{Sr} /{ }^{86} \mathrm{Sr}$ (Fig. 8a) and ${ }^{208} \mathrm{~Pb} /{ }^{206} \mathrm{~Pb}$ vs. ${ }^{87} \mathrm{Sr} /{ }^{86} \mathrm{Sr}$ (Fig. $8 \mathrm{~b}$ ), the Ischia and Neapolitan District magmas, along with Tyrrhenian Sea basalts suggest mantle metasomatism by crustal material with radiogenic ${ }^{87} \mathrm{Sr} /{ }^{86} \mathrm{Sr}$ similar to the other volcanic rocks of Aeolian Islands and Roman Magmatic Province, although affecting a different pre-enrichment mantle source.

Ischia volcano, along with other volcanoes of the Neapolitan District, represents the product of subduction of the Adriatic-Ionian plate toward west and northwest underneath the Eurasian plate (e.g., Wortel \& SPAKMAn, 2000; Mattei et alii, 2004; Faccenna et alii, 2010, for a review). On the basis of geophysical studies (e.g., GVIRTZMAN \& NuR, 2001; Faccenna et alii, 2001; 2007, 2010), the Adriatic-Ionian plate underneath the Neapolitan District is currently flattened and located at the transition zone between the asthenospheric mantle and the lower mantle (400 - $600 \mathrm{~km}$ depth). The asthenospheric mantle has been liable to experience metasomatic processes due to interaction with melt/supercritical fluids originating from the down-going Adriatic-Ionian slab. The $\mathrm{Sr}, \mathrm{Nd}, \mathrm{Pb}$, and Hf isotope signature of the mantle source of the Neapolitan District magmas will therefore depend upon the radiogenic isotope composition and the time related parent-daughter characteristics of the subducting components.

The radiogenic isotope signature of the convective asthenospheric mantle prior to subduction enrichment process(es), can be estimated using the transitional MORBs generated by asthenosphere upwelling in the central Tyrrhenian Sea basin (Beccaluva et alii, 1990; GASPERINI et alii, 2002) as also suggested in other studies on the subduction process in the Neapolitan District (e.g., D’Antonio et alii, 1999; Mazzeo et alii, 2014). The estimated radiogenic isotope signature of the convective asthenospheric mantle is intermediate between DMM and E-DMM (WORKMAN \& HART, 2005), and although speculative, it is not critical to the model proposed below, as its low trace element budget is overwhelmed by the trace element and isotopic signal of the subducting components during the recent enrichment process(es).

The subducted Adriatic-Ionian oceanic slab consists of both sediment, basalt, and oceanic lithospheric mantle. In terms of the trace element budget delivered to the overlying convective asthenospheric mantle, the contribution of the oceanic lithospheric mantle, commonly regarded as a refractory harzburgite, is negligible, excluding any $\mathrm{H}_{2} \mathrm{O}$ released during the dehydration of serpentine, chlorite
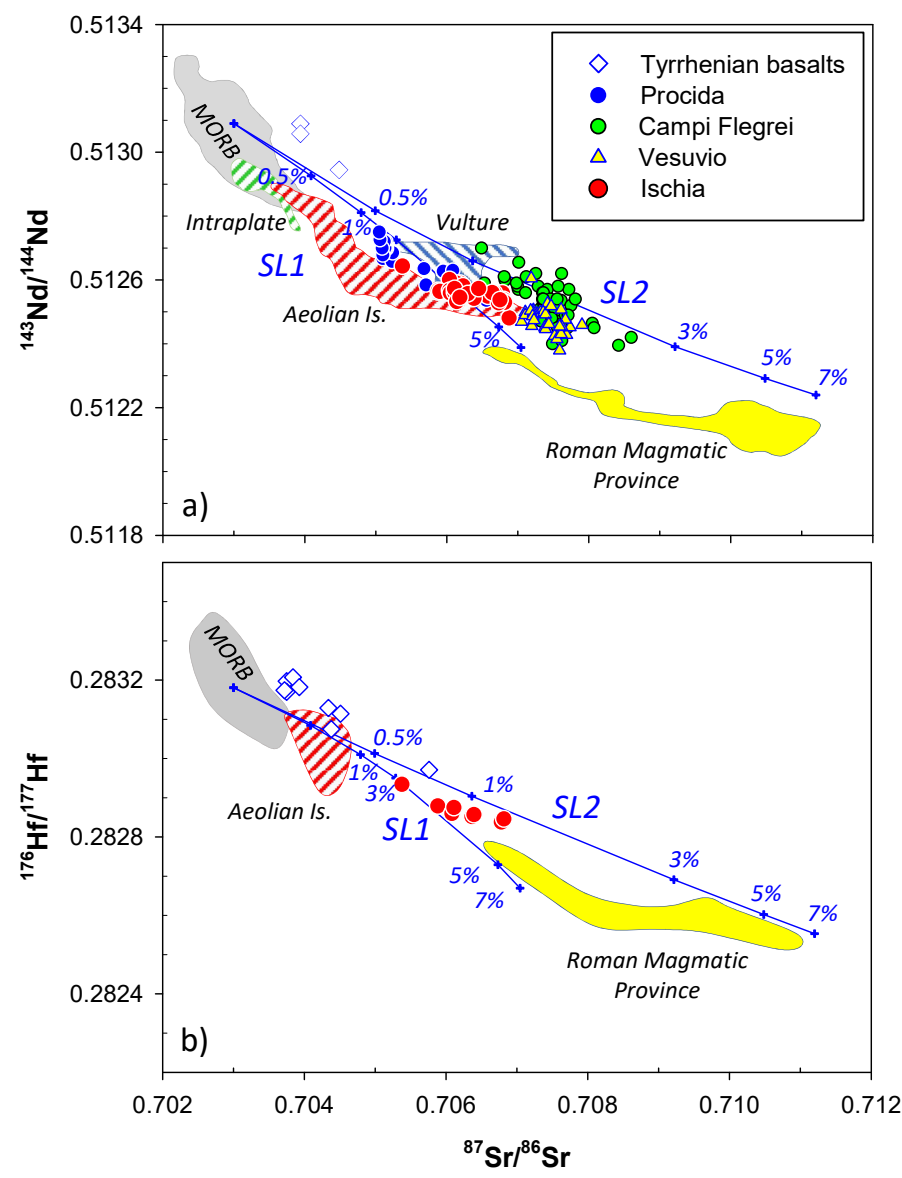

Fig. 7 - Model of the enrichment process of the mantle wedge beneath Ischia, and possibly the entire Neapolitan District, magmas: a) ${ }^{143} \mathrm{Nd} /{ }^{144} \mathrm{Nd}$ vs. ${ }^{87} \mathrm{Sr} /{ }^{86} \mathrm{Sr}$, and b) ${ }^{176} \mathrm{Hf} /{ }^{177} \mathrm{Hf}$ vs. ${ }^{87} \mathrm{Sr} /{ }^{86} \mathrm{Sr}$. The MORBtype pre-enrichment mantle is metasomatised by supercritical liquids (SL1, SL2) originating from the two major components of the Adriatic-Ionian subducted slab (altered oceanic basalt and pelagic sediments). The two blue lines with small crosses represent the shift of the mantle wedge composition caused by two composite supercritical liquids (SL1, SL2), formed by $40 \%$, and $80 \%$ relative of the sediment-derived supercritical liquid. For the sake of clarity, the absolute amount of each composite supercritical liquid (from $0.1 \%$ to $7 \%$ ) metasomatising the MORB-type mantle wedge is indicated only for some tick marks. The fields of other recent volcanic rocks outcropping in Central and Southern Italy are also reported. Tyrrhenian basalts data source are from GASPERINI et alii (2002); fields for MORB, Intraplate, Vulture, Aeolian Island and Roman Magmatic Province are from SALTER \& STRAcke (2003), D'Antonio et alii (1999), AJuso et alii (1998), Conticelli et alii (2002, 2015), Avanzinelli et alii (2008, 2012, 2014, 2018), Francalanci et alii (2007), Tommasini et alii (2007); other data source as in Fig. 5. 

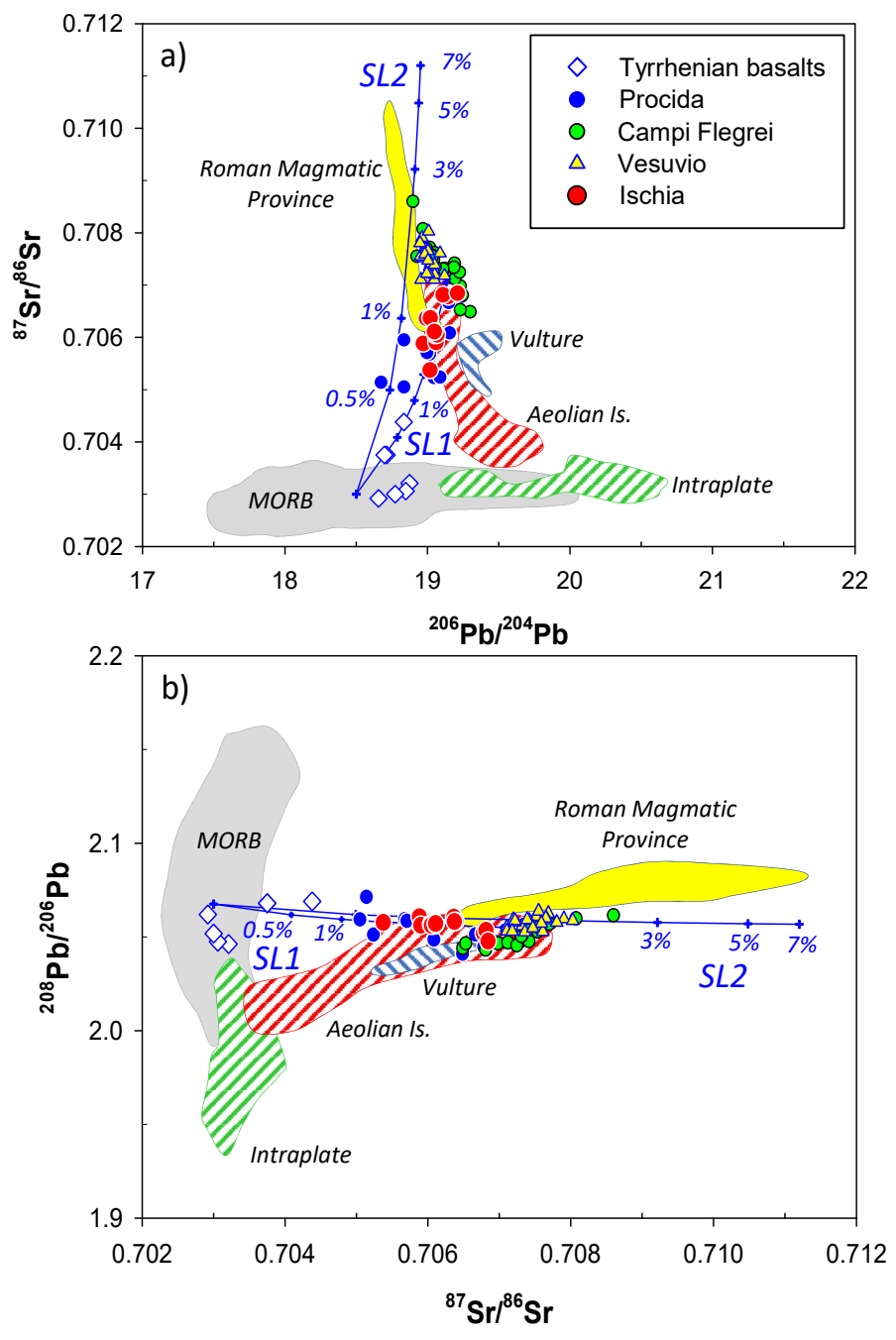

Fig. 8 - Model of the enrichment process of the mantle wedge beneath Ischia, and possibly the entire Neapolitan District, magmas: a) ${ }^{87} \mathrm{Sr} /{ }^{86} \mathrm{Sr}$ vs. ${ }^{206} \mathrm{~Pb} /{ }^{204} \mathrm{~Pb}$, and b) ${ }^{208} \mathrm{~Pb} /{ }^{206} \mathrm{~Pb}$ vs. ${ }^{87} \mathrm{Sr} /{ }^{86} \mathrm{Sr}$. The MORB-type preenrichment mantle is metasomatised by supercritical liquids (SL1, SL2) originating from the two major components of the AdriaticIonian subducted slab (altered oceanic basalt and pelagic sediments) The two blue lines with small crosses represent the shift of the mantle wedge composition caused by two composite supercritical liquids (SL1, SL2), formed by $40 \%$, and $80 \%$ relative of the sediment-derived supercritical liquid. For the sake of clarity, the absolute amount of each composite supercritical liquid (from $0.1 \%$ to $7 \%$ ) metasomatising the MORB-type mantle wedge is indicated only for some tick marks. The fields of other recent volcanic rocks outcropping in Central and Southern Italy are also reported. Data source as in Fig. 7.

and other high-pressure $\mathrm{H}_{2} \mathrm{O}$-bearing phases (e.g., STALDER et alii, 2001; IWAMORI, 2004; RÜPKE et alii, 2004).

On the other hand, the two major components of the oceanic crust (altered basalt, including the intrusive counterpart, and pelagic sediment cover) play a fundamental role in recycling lithophile elements back into the mantle wedge through the prograde dehydration reactions occurring during slab subduction (e.g., PEAcock et alii, 1994; ElliotT et alii, 1997; HaWKESWORTH et alii, 1997; Turner et alii, 1997; Plank \& LAMgmuir, 1998). The fate of the Adriatic-Ionian oceanic crust in the subduction factory has been quantitatively modelled in a study of TomMASINI et alii (2007) on Stromboli volcano and, as a first attempt, we have applied their results to mantle metasomatism underneath the Neapolitan District; the same model was also recently used (AvANZINELLI et alii, 2018) as a starting point to discuss the U-Th disequilibria, ${ }^{238} \mathrm{U} /{ }^{235} \mathrm{U}$ and Sr-Nd$\mathrm{Pb}$ compositions of volcanic rocks from Vesuvio.

The mantle source of the Neapolitan District magmas can be reproduced by metasomatism of the MORB-type pre-enrichment mantle wedge with different mixtures of supercritical liquids (e.g., KESSEL et alii, 2005) originating from the two major components of the subducted slab (altered oceanic basalt and pelagic sediments). And, as an example, we have reported in Figs. 7 and 8 two mixing lines delineating the change of radiogenic isotope signature of the Tyrrhenian MORB-type mantle due to metasomatism by composite supercritical liquids. The two composite supercritical liquids represent a mixture between those originating from the subducted altered oceanic basalt and pelagic sediment, namely: SL1, $40 \%$ sediment-derived and $60 \%$ altered oceanic basalt-derived supercritical liquid; SL2, $80 \%$ sediment-derived and $20 \%$ altered oceanic basalt-derived supercritical liquid (the composition of these two supercritical liquids are reported in Tommasini et alii, 2007). In terms of absolute amounts, the mantle source underneath the Neapolitan District requires $<5 \%$ of a composite supercritical liquid intermediate between SL1 and SL2 to acquire the radiogenic isotope signature of the Neapolitan District magmas, as also reported by MAzzeo et alii (2014). Remarkably, the Tyrrhenian Sea basalts are also aligned along this trend (Figs. 7 and 8), suggesting a scenario of pervasive metasomatisation, albeit in very low amount $(<0.5 \%)$, of the entire asthenospheric mantle forming the Tyrrhenian basin.

In addition to metasomatism by composite supercritical liquids, the mantle source of the Neapolitan District magmas must have experienced another recent $(<350 \mathrm{ka})$ mantle enrichment process to account for ${ }^{238} \mathrm{U}$ excess measured in volcanic products of Ischia and Vesuvio (Avanzinelli et alii, 2008; 2018). Combining $\mathrm{U}$-series and ${ }^{238} \mathrm{U} /{ }^{235} \mathrm{U}$ isotopes of Vesuvio, AvANZINELLI et alii (2018) proposed that this further mantle enrichment can be explained with the addition of a relatively small amount $(1-2.5 \%)$ of a carbonate-rich sedimentary material melt recycled through subduction. These intriguing topics shall be dealt with in future studies that can spread out new interesting scenarios on the asthenospheric mantle evolution in this sector of the Apennine belt.

\section{CONCLUDING REMARKS}

We have presented a comprehensive radiogenic isotope ( $\mathrm{Sr}, \mathrm{Nd}, \mathrm{Pb}, \mathrm{Hf})$ study focused on the mantle source of Ischia magmas, which can have inferences of the entire Neapolitan District magmas. No parental mantle-derived magma outcrops at Ischia, making it difficult to decipher the radiogenic isotope signature of the mantle source.

As a first approximation, $\mathrm{Sr}$ and $\mathrm{Nd}$ isotope composition of Ischia magmas is consistent with a first step of EC-AFC followed by a second step of closed system fractional crystallisation. This has permitted to derive an inverse modelling to unravel the radiogenic isotope mantle source signature devoid of the first EC-AFC process occurring en route to the surface. $\mathrm{Pb}$ isotopes, however, are not consistent with such a process, unequivocally 
demonstrating that also the first evolutive step cannot be explained by open system processes, and point to mantle source heterogeneity as the main parameter controlling radiogenic isotope variability of Ischia, and possibly the entire Neapolitan District magmas.

This is suggestive of a magmatic reservoir at Ischia consisting of several isolated batches of magma with distinct radiogenic isotope compositions that evolve along similar liquid lines of descent (e.g., CASALINI et alii, 2017), recalling recent models of complex plumbing systems, made up of multiple discrete melt pockets, isolated by largely crystalline mush portions, and maintained in a steady-state thermal flux regime with no mass exchange, and with reactivation shortly before eruption (e.g., CASHMAN \& GIORDANO, 2014).

The main results obtained from our study demonstrate that the radiogenic isotope composition of evolved magmas at Ischia, and possibly Procida, Vesuvio, and Campi Flegrei, represents the original isotopic signature of their mantle source, and permit to decipher mantle enrichment processes. The magmas of Ischia, and possibly of the entire Neapolitan District, derive from a MORBtype asthenospheric mantle source which experienced metasomatic enrichment by composite supercritical liquids originating from the altered oceanic basalt and pelagic sediment of the subducting Adriatic-Ionian slab.

As a corollary, given the complex magmatic reservoir underneath Ischia, it is tempting to speculate that the entire Neapolitan District could form a large complex magma chamber (some $50 \times 20 \mathrm{~km}$ wide) consisting of multiple, isotopically distinct, melt lenses separated by crystal mush zones.

\section{ACKNOWLEDGEMENTS}

This study benefitted from discussions and criticism with Eleonora Braschi and Lorella Francalanci. We would like to thank Maurizio Ulivi for helping with $\mathrm{Sr}$ and Nd isotope analyses in Firenze. Tim Elliott provided access to the Thermo Finnigan Neptune facility in Bristol for $\mathrm{Pb}$ isotope analyses. Comments by J.C. White and an anonymous reviewer, and careful editorial handling by W. Cavazza and A. Renzulli, greatly improved the manuscript. This research was supported by PRIN 20158A9CBM to SC and 2015EC9PJ5 to RA.

\section{REFERENCES}

ACOCELLA V. \& FUNICIELLO R. (1999) - The interaction between regional and local tectonic during resurgent doming: the case of the island of Ischia, Italy. J. Volcanol. Geoth. Res., 88, 109-123.

Acocella V., Cifelli F., Funiciello R. (2001) - The control of overburden thickness on resurgent domes: insights from analogue models. J. Volcanol. Geoth. Res, 111, 137-153.

Acocella V., Funiciello R., Marotta E., Orsi G. \& De Vita S. (2004) - The role of extensional structures on experimental calderas and resurgence. J. Volcanol. Geoth. Res, 129, 199-217.

Appleton J.D. (1972) - Petrogenesis of Potassium-rich Lavas from the Roccamonfina Volcano, Roman Region, Italy. J. Petrol., 13, 425 456.

Avanzinelli R., Boari E., Conticelli S., Francalanci L., Guarnieri L., Perini G., Petrone C.M., Tommasini S. \& Ulivi M. (2005) - High precision $\mathrm{Sr}, \mathrm{Nd}$, and $\mathrm{Pb}$ isotopic analyses using new generation Thermal Ionisation Mass Spectrometer: aims and perspective for Isotope Geology Applications. Period. Miner., 74, 147-166.

Avanzinelli R., Braschi E., Marchionni S. \& Bindi L. (2014) - Mantle melting in within-plate continental settings: $\mathrm{Sr}-\mathrm{Nd}-\mathrm{Pb}$ and $\mathrm{U}$-series isotope constraints in alkali basalts from the Sicily Channe (Pantelleria and Linosa Islands, Southern Italy). Lithos, 188, 113 129.
Avanzinelli R., Casalini M., Elliott T. \& Conticelli S. (2018) - Carbon fluxes from subducted carbonates revealed by uranium excess at Mount Vesuvius, Italy. Geology, doi.org/10.1130/G39766.1. Avanzinelli R., Elliott T., Tommasini S., Conticelli S. (2008) Constraints on the Genesis of Potassium-rich Italian Volcanic Rocks from U/Th Disequilibrium. J. Petrol., 49, 195-223.

Avanzinelli R., Lustrino M., Mattei M., Melluso L. \& Conticelli S. (2009) - Potassic and ultrapotassic magmatism in the circumTyrrhenian region: significance of carbonated pelitic vs. pelitic sediment recycling at destructive plate margin. Lithos, 133, 213 227.

Avanzinelli R., Sapienza G.T. \& Conticelli S. (2012) - The Cretaceous to Paleogene within-plate magmatism of Pachino-Capo Passero (southeastern Sicily) and Adria (La Queglia and Pietre Nere, southern Italy): geochemical and isotopic evidence against a plumerelated origin of circum-Mediterranean magmas. Eur. J. Mineral., 24, 73-96.

Ayuso R.A., De Vivo B., Rolandi G., Seal II R.R. \& Paone A. (1998) - Geochemical and isotopic $\mathrm{Nd}-\mathrm{Pb}-\mathrm{Sr}-\mathrm{O}$ variations bearing on the genesis of volcanic rocks from Vesuvius, Italy. In: Spera F.J., De Vivo B., Ayuso R.A., Belki H.E. (eds), Vesuvius Special Issue. J. Volcanol. Geotherm. Res., 82, 53-78.

Baker J., Peate D., Waight T. \& Meyzen C. (2004) - Pb isotopic analysis of standards and samples using a 207Pb-204Pb double spike and thallium to correct for mass bias with a double-focusing MC-ICPMS. Chem. Geol., 211, 275-303.

Beccaluva L., Bonatti E., Dupuy C., Ferrara G., Innocenti F., Lucchini F., Macera P., Petrini R., Rossi P. L., Serri G., Seyler M. \& Siena F. (1990) - Geochemistry and mineralogy of volcanic rocks from ODP sites 650, 651, 655 and 654 in the Tyrrhenian Sea. In: STEWART N.J. (ed), Proceedings of the Ocean Drilling Program, Scientific Results. U.S. Government Printing Office, Washington D. C., 107, 49-74.

Beccaluva L., Di Girolamo P. \& Serri G. (1991) - Petrogenesis and tectonic setting of the Roman Volcanic Province, Italy. Lithos, 26, 191-221.

Brown R.J., Civetta L., Arienzo I., D’Antonio M., Moretti R., Orsi G., Tomlinson E.L., Albert P.G. \& Menzies M.A. (2014) - Geochemical and isotopic insights into the assembly, evolution and disruption of a magmatic plumbing system before and after a cataclysmic caldera collapse eruption at Ischia volcano (Italy). Contrib. Mineral. Petrol., 168, 1-23.

Brown R.J., Orsi G. \& DE VITA S. (2008) - New insights into Late Pleistocene explosive volcanic activity and caldera formation on Ischia (southern Italy). B. Volcanol., 70, 583-603.

Buchner G., Italiano A. \& Vita-Finzi C. (1996) - Recent uplift of Ischia southern Italy. Geol. Soc. Sp., 110, 249-252.

Casalini M., Avanzinelli R., Heumann A., de Vita S., Sansivero F., Conticelli S. \& Tommasini S. (2017) - Geochemical and radiogenic isotope probes of Ischia volcano, Southern Italy: Constraints on magma chamber dynamics and residence time. Am. Mineral., 102 262-274.

CASHMAN K.V. \& GIORDANO G. (2014) - Calderas and magma reservois. J. Volcanol. Geoth. Res., 288, 28-45.

Civetta L., Gallo G. \& Orsi G. (1991) - Sr-and Nd-isotope and traceelement constraints on the chemical evolution of the magmatic system of Ischia (Italy) in the last $55 \mathrm{ka}$. J. Volcanol. Geoth. Res., 46, 213-230.

Civetta L., Orsi G., Pappalardo L., Fisher R.V., Heiken G. \& Ort M. (1997) - Geochemical zoning, mingling, eruptive dynamics and depositional processes - the Campanian Ignimbrite, Campi Flegrei caldera, Italy. J. Volcanol. Geoth. Res., 75, 183-219.

Collerson K.D., Kamber B.S. \& Schoenberg R. (2002) - Applications of accurate, high-precision $\mathrm{Pb}$ isotope ratio measurements by multicollector ICP-MS. Chem. Geol., 188, 65-83.

Conticelli S. \& Peccerillo A. (1992) - Petrology and geochemistry of potassic and ultrapotassic volcanism in Central Italy: petrogenesis and interferences on the mantle source. Lithos, 28, 221-240.

Conticelli S., Avanzinelli R., Ammannati E. \& Casalini M. (2015) - The role of carbon from recycled sediments in the origin of ultrapotassic igneous rocs in the Central Mediterranean. Lithos, 232, 174-196.

Conticelli S., D’Antonio M., Pinarelli L. \& Civetta L. (2002) - Source contamination and mantle heterogeneity in the genesis of Italian potassic and ultrapotassic volcanic Rocks: $\mathrm{Sr}-\mathrm{Nd}$-Pb Isotope data from Roman Province and Southern Tuscany. Miner. Petrol., 74, 189-222. 
Conticelli S., Guarnieri L., Farinelli A., Mattei M., Avanzinelli R., Bianchini G., Boari E., Tommasini S., Tiepolo M., Prelévic D. \& Venturelli G. (2009) - Trace elements and $\mathrm{Sr}$ - $\mathrm{Nd}$-Pb isotopes of $K$-rich to shoshonitic, and calc-alkalic magmatism of the Western Mediterranean region: Genesis of ultrapotassic to calc-alkaline magmatic associations in a post-collisional geodynamic setting. Lithos, 107, 68-92.

Conticelli S., Laurenzi M.A., Giordano G., Mattei M., Avanzinelli R. Melluso L., Tommasini S., Boari E., Cifelli F. \& Perini G. (2010) - Leucite-bearing (kamafugitic/leucititic) and -free (lamproitic) ultrapotassic rocks and associated shoshonites from Italy: constraints on petrogenesis and geodynamics. In: Beltrando M., Peccerillo A., Mattei M., Conticelli S., Doglioni C. (eds), The Geology of Italy. J. Virtual Explorer, 36, p.20.

Conticelli S., Melluso L., Perini G., Avanzinelli R. \& Boari E. (2004) Petrologic, geochemical and isotopic characteristics of potassic and ultrapotassic magmatism in Central-Southern Italy: inferences on its genesis and on the nature of mantle sources. Period. Mineral. 73, 135-164.

Crisci G.M., De Francesco A.M., Mazzuoli R., Poli G. \& Stanzione D. (1989) - Geochemistry of the recent volcanics of Ischia Island, Italy: Evidence of crystallization and magma mixing. Chem. Geol., 78, 15-33.

D’Antonio M., Civetta L. \& Di Girolamo P. (1999) - Mantle source heterogeneity in the Campanian Region (South Italy) as inferred from geochemical and isotopic features of mafic volcanic rocks with shoshonitic affinity. Miner. Petrol., 67, 163-192.

D’Antonio M., Tonarini S., Arienzo I., Civetta L. \& Di Renzo V. (2007) Components and processes in the magma genesys of the Phleagran Volcanic District, southern Italy. In: Beccaluva L., Bianchini G. Wilson M. (eds), Cenozoic volcanism in the Mediterranean Area. Geol. S. Am. S., 418, p. 203-220.

D’Antonio M., Tonarini S., Arienzo I., Civetta L., Dallai L., Moretti R., Orsi G., Andria M. \& Trecalli A. (2013) - Mantle and crustal processes in the magmatism of the Campanian region: inferences from mineralogy, geochemistry, and $\mathrm{Sr}-\mathrm{Nd}-\mathrm{O}$ isotopes of young hybrid volcanics of the Ischia island (South Italy). Contrib. Mineral. Petrol., 165, 1173-1194.

De Astis G., Pappalardo L. \& Piochi M. (2004) - Procida volcanic history: new insights into the evolution of the Phlegraean Volcanic District (Campania region, Italy). B. Volcanol., 66, 622-641.

De Vita S., Sansivero F., Orsi G. \& Marotta E. (2006) - Cyclical slope instability and volcanism related to volcano-tectonism in resurgent calderas: The Ischia Island (Italy) case study. Eng. Geol., 86, 148-165.

De Vita S., Sansivero F., Orsi G., Marotta E. \& Piochi M. (2010) Volcanological and structural evolution of the Ischia resurgent caldera (Italy) over the past $10 \mathrm{ka}$. In: GropPELLI G., VIERECK-GoETTE L. (eds), Stratigraphy and geology of volcanic areas. Geol. S. Am. S., 464, 193-239.

Del Moro A., Fornelli A., Piccarreta G. (2000) - Disequilibrium melting in granulite-facies metasedimentary rocks of the Northern Serre (Calabria-Southern Italy). Miner. Petrol., 70(1), 89-104.

Del Moro A., Fulignati P., Marianelli P. \& Sbrana, A. (2001) - Magma contamination by direct wall-rock interaction: constraints from xenoliths from the walls of a carbonate-hosted magma chamber (Vesuvius 1944 eruption). J. Volcanol. Geotherm. Res., 112, 15-24.

Della Seta M., Marotta R., Orsi G., de Vita S., Sansivero F. \& Fredi P. (2012) - Slope instability induced by volcano-tectonics as an additional source of hazard in active volcanic areas: the case of Ischia island (Italy). B. Volcanol., 74(1), 79-106.

Di Girolamo P., Melluso L., Morra V. \& Secchi F.A.G. (1995) - Evidence of interaction between mafic and differentiated magmas in the youngest phase of activity at Ischia Island (Italy). Period. Mineral., 64, 393-411.

Dickin A. P. (1995) - Radiogenic Isotope Geology. Cambridge University Press, $452 \mathrm{p}$.

Downes H., Shaw A., Williamson B.J. \& Thirlwall M.F. (1997) Hercynian granodiorites and monzogranites, Massif Central, France. Chem. Geol., 136, 99-122.

Elliott T.R., Plank T., Zindler A., White W., Bourdon B. (1997) -Element transport from slab to volcanic front at the Mariana arc. J. Geophys. Res., 102, 14991-15019.

Faccenna C., Becker T.W., Lallemand S., Lagabrielle Y., Funiciello F. \& Piromallo C. (2010) - Subduction-triggered magmatic pulses: A new class of plumes?. Earth Planet. Sc. Lett., 299(1), 54-68.
Faccenna C., Funiciello C., Civetta L., D’Antonio M., Moroni M. \& Piromallo C. (2007) - Slab disruption, mantle circulation, and the opening of the Tyrrhenian basins. In: Beccaluva L., Bianchini G., Wilson M. (eds), Cenozoic Volcanism in the Mediterranean area. Geol. S. Am. S., 418, 153-169.

Faccenna C., Funiciello F., Giardini D. \& Lucente P. (2001) - Episodic back-arc extension during restricted mantle convection in the Central Mediterranean. Earth Planet. Sc. Lett., 187, 105-116.

Fornelli A., Piccarreta G., Del Moro A. \& Acouafredda P. (2002) Multi-stage melting in the lower crust of the Serre (Southern Italy). J. Petrol., 43, 2191-2217.

Francalanci L., Avanzinelli R., Tommasini S. \& Heuman A. (2007) - A west-east geochemical and isotopic traverse along the volcanism of the Aeolian Island arc, southern Tyrrhenian Sea, Italy: Inferences on mantle source processes. Geol. Soc. Sp., 418, 235-263.

Gasperini D., Blichert-Toft J., Bosh D., Del Moro A., Macera P. \& Albarede F. (2002) - Upwelling of deep Mantle material through a plate window: evidence from geochemistry of Italian Basaltic Volcanics. J. Geophys. Res., 107, 2367-2386.

Gillot P.Y., Chiesa S., Pasquarè G. \& Vezzoli L. (1982) - 33.000 yr K/Ar dating of the volcano-tectonics horst of the island of Ischia, Gulf of Naples. Nature, 229, 242-245.

Gualda G.A.R., Ghiorso M.S., Lemons R.V. \& Carley T.L. (2012) Rhyolite-MELTS: A modified calibration of MELTS optimized for silica-rich, fluid-bearing magmatic systems. J. Petrol., 53, 875-890.

GVIrTZMAn Z. \& NuR A. (2001) - Residual topography, lithospheric structure and sunken slabs in the central Mediterranean. Earth Planet. Sc. Lett., 187, 117-130.

Hawkesworth C.J., Turner S.P., Peate D.W., McDermott F. \& van CARlsteren P. (1997) - U-Th isotopes in arc magmas: implications for element transfer from the subducted crust. Science, 276, 551555.

Iacono-Marziano G., Gaillard F., Scaillet B., Pichavant M. \& Chiodini, G. (2009) - Role of non-mantle $\mathrm{CO}_{2}$ in the dynamics of volcano degassing: the Mount Vesuvius example. Geology, 37, p. 319-322.

IwAMORI H. (2004) - Phase relations of peridotites under $\mathrm{H}_{2} \mathrm{O}$-saturated conditions and ability of subducting plates for transportation of $\mathrm{H}_{2} \mathrm{O}$. Earth Planet. Sc. Lett., 227, 57-71.

Kessel R., Schmidt M.W., Ulmer P. \& Pettke T. (2005) - Trace element signature of subduction-zone fluids, melts and supercritical liquids at 120-180 km depth. Nature, 437, 724-727.

Le Maitre R. W., Streickeisen A., Zanettin B., Le Bas M. J., Bonin B., Bateman P., Bellieni G., Dudek A., Efremova S., Keller J., Lameyre J., Sabine P.A., Schmid R., Sørensen H. \& Woolley A. R. (2002) Igneous Rocks. A classification and glossary of terms. LE MAITRE, R. W. (ed), Cambridge University Press, Cambridge, 236 p.

Mattei M., D’Agostino N., FAccenna C., Piromallo C. \& Rossetti F. (2004) - Some remarks on the geodynamics of the Italian region. Period. Mineral., 73, 7-27

Mazzeo F.C., D’Antonio M., Arienzo M., Aulinas I., Di Rienzo V. \& Gimeno D. (2014) - Subduction-related enrichment of the Neapolitan volcanoes (Southern Italy) mantle source: New constraints on the characteristics of the slab-derived components. Chem. Geol., 386 165-183.

Melluso L., Morra V., Guarino R., de' Gennaro R., Franciosi L. \& GRIFA C. (2014) - The crystallization of shoshonitic to peralkaline trachyphonolitic magmas in a $\mathrm{H}_{2} \mathrm{O}-\mathrm{Cl}-\mathrm{F}$-rich environment at Ischia (Italy), with implications for the feeder system of the Campania Plain volcanoes. Lithos, 210, 242-259.

Monti L., Sbrana A., Toccaceli R.M., Faccenna C., Fulignati P., Giudetti G., Marianelli P., Deino A., Bravi S., D’Argenio B., and others. (2010) - Carta Geologica d'Italia alla scala 1:50.000-Foglio 464 Isola d'Ischia, Progetto Carg. Regione Campania, ISPRA, SystemCart, Roma; www.isprambiente.gov.it/Media/ carg/464 ISOLA DISCHIA/Foglio.html.

Moretti R., Arienzo I., Orsi G., Civetta L. \& D'Antonio M. (2013) - The deep plumbing system of Ischia: a physico-chemical window on the fluid saturated and $\mathrm{CO}_{2}$-sustained Neapolitan volcanism (southern Italy). J. Petrol., 54, 951-984.

Nebel O., Morel M.L.A. \& Vroon P.Z. (2009) - Isotope dilution determinations of $\mathrm{Lu}, \mathrm{Hf}, \mathrm{Zr}, \mathrm{Ta}$ and $\mathrm{W}$, and $\mathrm{H}$ f isotope compositions of NIST SRM 610 and 612 glass wafers. Geostand. Geoanal. Res., 33(4), 487-499.

Orsi G., De Vita S., Di Vito M., Isaia R., Nave R. \& Heiken G. (2003) -Facing volcanic and related hazards in the Neapolitan area. In: 
Heiken G., Fakundiny R., Sutter J. (eds), Earth Sciences in City. A Reader, American Geophysical Union, Washington, 121-170.

ORSI G., GALLO G. \& ZANCHI A. (1991) - Simple-shearing block resurgence in caldera depressions. A model from Pantelleria and Ischia. J. Volcanol. Geoth. Res., 47, 1-11.

Orsi G., Piochi M., Campajola L., D’Onofrio A., Gialanella L. \& Terrasi F. (1996) $-{ }^{14} C$ geochronological constraints for the volcanic history of the island of Ischia (Italy) over the last 5000 years. J. Volcanol. Geoth. Res., 71, 249-257.

Orsi G., Gallo G., Heikien G., Wohletz K., Yu E. \& Bonani G. (1992) - A comprehensive study of pumice formation and dispersal: the Cretaio Tephra of Ischia (Italy). J. Volcanol. Geoth. Res., 53, 329354.

Pappalardo L., Civetta L., D’Antonio M., Deino A., Di Vito M.A., Ors G., Caradente A., De Vita S., Isaia R. \& Piochi M. (1999) - Chemical and Sr-isotopical evolution of the Phlegraean magamtic system before the Campanian Ignimbrite eruptions J. Volcanol. Geoth. Res., 91, 141-166.

Peacock S.M., Rushmer T. \& Thompson A.B. (1994) - Partial melting of subducting oceanic crust. Earth Planet. Sc. Lett., 121, 227-244.

Peccerillo A. (1999) - Multiple mantle metasomatism in centralsouthern Italy: geochemical effects, timing and geodynamic implications. Geology, 27(4), 315-318.

Peccerillo A. (2001) - Geochemical similarities between the Vesuvio, Phlegrean Fields and Stromboli volcanoes: petrogenetic, geodynamic and volcanological implications. Miner. Petrol., 73, 93-105.

Peccerillo A. (2005) - Plio-Quaternary Volcanism in Italy. SpringerVerlag Berlin Heidelberg, 365 p.

Piochi M., Civetta L. \& Orsi G. (1999) - Mingling in the magmatic system of Ischia in the past $5 \mathrm{ka}$. Miner. Petrol., 66, 227-258.

Plank T. \& Langmuir C.H. (1998) - The chemical composition of subducting sediment and its consequences for the crust and mantle. Chem. Geol., 145, 325-394.

Poli S., Chiesa S., Gillot P.Y., Gregnain A. \& Guichard F. (1987) Chemistry versus time in the volcanic complex of Ischia (Gulf of Naples, Italy) evidence of successive magmatic cycles. Contrib. Mineral. Petrol., 95, 322-235.

Poli S., Chiesa S., Gillot P.Y., Guichard F. \& Vezzoli L. (1989) - Time dimension in the geochemical approach and hazard estimates of a volcanic area: the isle of Ischia case (Italy). J. Volcanol. Geoth. Res., 36, 327-335.

Rollinson H. (1993) - Using Geochemical Data: Evaluation, Presentation, Interpretation. Longman Group, UK, 352 p.

RÜPKe L.H., Phipps Morgan J., Hort M. \& Connolly J.A.D. (2004) Serpentine and the subduction zone water cycle. Earth Planet. Sc. Lett., 223, 17-34.

SPERA F.J. \& Borhson W.A. (2001) - Energy-Constrained Open-System Magmatic Processes I: General Model and Energy-Constrained
Assimilation and Fractional Crystallization (EC-AFC) Formulation. J. Petrol., 42, 999-1018.

Stalder R., Ulmer P., Thompson A.B. \& GÜnter D. (2001) - High pressure fluids in the system $\mathrm{MgO}-\mathrm{SiO}_{2}-\mathrm{H} 2 \mathrm{O}$ under upper mantle conditions. Contrib. Mineral. Petrol., 140, 607-618.

Salter V.J. \& Stracke A. (2004) - Composition of the depleted mantle. Geochem. Geophy. Geosy., 5(5).

Thirlwall M.F. (2000) - Inter-laboratory and other errors in Pb isotopes analyses investigated using a ${ }^{207} \mathrm{~Pb}^{204} \mathrm{~Pb}$ double spike. Chem. Geol., 163, 299-322.

Tномрson A.B. (1996) - Fertility of crustal rocks during anatexis. Geol. S. Am. S., 315, 1-10. Edimburgh: Earth Sciences, 87, 1-10.

Tibaldi A. \& Vezzoli L. (2004) - A new type of volcano flank failure: The resurgent caldera sector collapse, Ischia, Italy. Geophys. Res. Lett., 31, L14605.

Tomlinson E.L., Albert P.G., Wulf S., Brown R.J., Smith V.C., Keller J., Orsi G., Bourne A.J. \& Menzies M.A. (2014) - Age and geochemistry of tephra layers from Ischia, Italy: constraints from proximal-distal correlations with Lago Grande di Monticchio. J. Volcanol. Geoth. Res., 287, 22-39.

Tommasini S., Heumann A., Avanzinelli R. \& Francalanci L. (2007) The fate of high-angle dipping slabs in the subduction factory: An integrated trace element and radiogenic isotope ( $U, T h, \mathrm{Sr}, \mathrm{Nd}, \mathrm{Pb}$ study of Stromboli volcano, Aeolian Arc, Italy. J. Petrol., 48, 24072430.

Turner S.P., Hawkesworth C.J., Rogers N., Bartlett J., Worthington T., Hergt J., Pearce J. \& Smith I. (1997) - ${ }^{238} U-{ }^{230}$ Th disequilibria, magma petrogenesis and flux rates beneath the depleted TongaKermadec Island arc. Geochim. Cosmochim. Ac., 61, 4855-4884.

Vervoort J.D., Patchett P.J., Gehrels G.E. \& Nutmann A.P. (1996) Constraints on early differentiation from hafnium and neodymium isotopes. Nature, 379, 624-627.

Vezzoli L. (ed) (1988) - Island of Ischia. CNR Quaderni de "La ricerca scientifica", 114-10, p. 126.

Washington H.S. (1906) - The Roman Comagmatic Region. Carnegie Institution of Washington, Publication no 57, $199 \mathrm{p}$.

Weis D., KiefFer B., Maerschalk C., Barling J., de Jong J., Williams G.A., Hanano D., Pretorius W., Mattielli N., Scoates J.S., Goolaerts A., FIREDMAN R.M. \& MAHONEY J.B. (2006) - High-precision isotopic characterization of USGS reference materials by TIMS and MC-ICPMS. Geochem. Geophy. Geosy., 7, Q08006.

Woodhead J.D. \& Hergt J.M. (2000) - Pb-isotope analyses of USGS reference materials. Geostandard Newslett., 24, 33-38.

WORKMAN R.H. \& HART S.R. (2005) - Major and trace element composition of the depleted MORB mantle (DMM). Earth Planet. Sc. Lett., 231, 53-72.

Wortel M.J.R. \& SPAKMan W. (2000) - Subduction and slab detachment in the Mediterranean-Carpathian Region. Science, 290, 1910-1917.

Manuscript received 14 December 2017; accepted 03 March 2018; published 21 March 2018 editorial responsibility and handling by A. Renzulli 